\title{
Long-term deposition and condensation ice-nucleating particle measurements from four stations across the globe
}

\author{
Jann Schrod $^{1}$, Erik S. Thomson ${ }^{2}$, Daniel Weber ${ }^{1, a}$, Jens Kossmann ${ }^{1}$, Christopher Pöhlker $^{3}$, Jorge Saturno ${ }^{3, b}$, \\ Florian Ditas $^{3, \mathrm{c}}$, Paulo Artaxo ${ }^{4}$, Valérie Clouard ${ }^{5, \mathrm{~d}}$, Jean-Marie Saurel ${ }^{5}$, Martin Ebert ${ }^{6}$, Joachim Curtius ${ }^{1}$, and \\ Heinz G. Bingemer ${ }^{1}$ \\ ${ }^{1}$ Institute for Atmospheric and Environmental Sciences, Goethe University Frankfurt, Frankfurt am Main, Germany \\ ${ }^{2}$ Atmospheric Science, Department of Chemistry and Molecular Biology, University of Gothenburg, Gothenburg, Sweden \\ ${ }^{3}$ Biogeochemistry and Multiphase Chemistry Departments, Max Planck Institute for Chemistry, Mainz, Germany \\ ${ }^{4}$ Institute of Physics, University of Sao Paulo, São Paulo, Brazil \\ ${ }^{5}$ Institut de physique du globe de Paris, Université de Paris, Paris, France \\ ${ }^{6}$ Institute of Applied Geosciences, Technical University of Darmstadt, Darmstadt, Germany \\ ${ }^{a}$ now at: Federal Waterways Engineering and Research Institute, Karlsruhe, Germany \\ bnow at: Physikalisch-Technische Bundesanstalt, Braunschweig, Germany \\ ${ }^{c}$ now at: Hessisches Landesamt für Naturschutz, Umwelt und Geologie, Wiesbaden, Germany \\ ${ }^{d}$ now at: Géosciences Environnement Toulouse, Toulouse, France
}

Correspondence: Jann Schrod (schrod@iau.uni-frankfurt.de)

Received: 3 July 2020 - Discussion started: 4 August 2020

Revised: 23 October 2020 - Accepted: 31 October 2020 - Published: 22 December 2020

\begin{abstract}
Ice particle activation and evolution have important atmospheric implications for cloud formation, initiation of precipitation and radiative interactions. The initial formation of atmospheric ice by heterogeneous ice nucleation requires the presence of a nucleating seed, an ice-nucleating particle (INP), to facilitate its first emergence. Unfortunately, only a few long-term measurements of INPs exist, and as a result, knowledge about geographic and seasonal variations of INP concentrations is sparse. Here we present data from nearly 2 years of INP measurements from four stations in different regions of the world: the Amazon (Brazil), the Caribbean (Martinique), central Europe (Germany) and the Arctic (Svalbard). The sites feature diverse geographical climates and ecosystems that are associated with dissimilar transport patterns, aerosol characteristics and levels of anthropogenic impact (ranging from near pristine to mostly rural). Interestingly, observed INP concentrations, which represent measurements in the deposition and condensation freezing modes, do not differ greatly from site to site but usually fall well within the same order of magnitude. Moreover, short-term variability overwhelms all long-term trends and/or seasonality in the INP concentration at all locations.
\end{abstract}

An analysis of the frequency distributions of INP concentrations suggests that INPs tend to be well mixed and reflective of large-scale air mass movements. No universal physical or chemical parameter could be identified to be a causal link driving INP climatology, highlighting the complex nature of the ice nucleation process. Amazonian INP concentrations were mostly unaffected by the biomass burning season, even though aerosol concentrations increase by a factor of 10 from the wet to dry season. Caribbean INPs were positively correlated to parameters related to transported mineral dust, which is known to increase during the Northern Hemisphere summer. A wind sector analysis revealed the absence of an anthropogenic impact on average INP concentrations at the site in central Europe. Likewise, no Arctic haze influence was observed on INPs at the Arctic site, where low concentrations were generally measured. We consider the collected data to be a unique resource for the community that illustrates some of the challenges and knowledge gaps of the field in general, while specifically highlighting the need for more long-term observations of INPs worldwide. 


\section{Introduction}

Ice-nucleating particles (INPs) are a crucial element in cloud formation and precipitation processes (DeMott et al., 2010; Lohmann, 2015). INPs are a rare subclass of aerosol particles with special physicochemical properties that enable the first emergence of ice crystals by reducing the critical energy barrier for spontaneous nucleation (Vali et al., 2015). Known species of INPs include mineral dust, soil dust, and primary biological aerosol particles of terrestrial and marine origin, as well as organics and glassy aerosols (Kanji et al., 2017). In a supercooled and supersaturated cloud regime INPs may activate to ice crystals, which will then grow and possibly form secondary ice by splintering or other multiplication processes. Once grown to their critical size, crystals may initiate precipitation. This is especially important for mixed-phase clouds that consist of both supercooled water droplets and ice crystals. In the presence of ice crystals water droplets will evaporate, feeding the crystals with more water vapor, a phenomenon known as the Wegener-Bergeron-Findeisen process. It is well established that the majority of global precipitation is formed through this pathway, especially over continental regions and the midlatitude oceans (e.g., Mülmenstädt et al., 2015). INPs also influence local and global radiation budgets and related aerosol-cloud interactions by affecting the phase of clouds (Lohmann, 2015).

Ice nucleation research first received some scientific attention in the 1950s and 1960s, and since then interest has intensified, especially during the last 1 or 2 decades (DeMott et al., 2011). However, due to several difficulties in quantifying and characterizing INPs in the atmosphere, there are still large knowledge gaps concerning geographic and vertical distributions, seasonal and/or interannual variations, chemical composition, and sources of INPs. Although there have been significant advances in identifying some of the INP species of global relevance (e.g., Atkinson et al., 2013; O’Sullivan et al., 2015; Wilson et al., 2015; Hiranuma et al., 2019), understanding microscopic freezing processes (e.g., Marcolli, 2014; Kiselev et al., 2017; David et al., 2020), parameterizing INP concentrations (e.g., DeMott et al., 2010, 2015; Niemand et al., 2012), intercomparing INP instrumentation in standardized procedures (Hiranuma et al., 2015; DeMott et al., 2018; Hiranuma et al., 2019), and designing and characterizing new measurement techniques (e.g., Garimella et al., 2016; Schrod et al., 2016; Möhler et al., 2020), we are still far from having a complete picture. A major shortcoming is the lack of global coverage and continuous longer-term observations of INPs. Large regions of the earth (including whole continents and oceans) are underrepresented or even completely missed by INP measurements. For those regions where observations exist, measurements primarily cover periods of a few days or weeks. Very few published INP measurements qualify as long-term observations that cover multiple seasons or year-to-year variations. A further obstacle to INP monitoring was that many instruments were previously not suited for sustained, long-term monitoring tasks due to their complex and labor-intensive operating principles. However, recent developments in INP instrumentation and a shift in sampling focus may lead to more long-term INP measurements becoming publicly available now and/or in the near future (e.g., Schneider et al., 2020).

It is noteworthy that several projects in the early years of ice nucleation research actually succeeded in acquiring longer-term records of INP abundance. Although changes in instrumentation and sampling techniques sometimes make it difficult to utilize these decades-old results in an absolute sense, the trends and relative results are quite informative. For example, Soulage (1966) coordinated a regional network of nine European stations that synchronously collected samples during the summer of 1964. In that study INP samples were analyzed using mixing chambers at $-21^{\circ} \mathrm{C}$. In the resulting publication the author speculated that some positive anomalies in the record of INPs were associated with episodes of advected Saharan dust and/or might have been affected by industrial particles. From 1959 to 1962 Kline (1963) measured INPs for the US National Weather Service at 15 sites using an expansion type chamber that operated from -20 to $-24^{\circ} \mathrm{C}$. The measurements present evidence that terrestrial aerosol particles dominate the INP budget of the lower atmosphere. The geographic site-to-site variability was about an order of magnitude, while day-to-day fluctuations of up to several orders of magnitude were recorded at single sites. Bigg collected INPs on membrane filters across eastern Australia and New Zealand during several months of 1962-1964 (Bigg and Miles, 1964). Later he continued sampling in the marine boundary layer over large parts of the remote Southern Ocean around Australia from 1969 to 1972 (Bigg, 1973). Samples were analyzed in a thermal vapor diffusion chamber. Bigg's most striking results were (i) the similarity of INP abundances in the continental atmosphere and in the marine boundary layer and (ii) the occurrence of high concentrations of INPs in remote areas far west and east of the Australian continent. In another multi-year study from 1964 to 1968 the Austrian meteorological service (Zentralanstalt für Meteorologie und Geodynamik) measured the abundance of INPs at $-21^{\circ} \mathrm{C}$ using the method of Soulage (1965) at three sites, three times per day (Müller, 1969). That data also display a relatively high day-to-day variability of INP abundance. The sparseness of these few historic measurement efforts highlights the need for more long-term INP observations.

Measurements of cloud-active aerosols in remote and/or near-pristine environments are particularly rare and therefore inherently valuable. Such regions may be studied to gain insight into aerosol conditions in environments that are only marginally perturbed by humans. This information is needed to estimate the reference baseline of pre-industrial aerosol (Carslaw et al., 2017). Such a baseline is vital to the accurate evaluation of anthropogenic climate effects, as it is integral to the assessment of the anthropogenic contribution to present- 
day radiative forcing. All estimates of anthropogenic aerosol effects are highly sensitive to the assumed pre-industrial baseline, including the degree to which cooling aerosol effects have compensated for the radiative forcing by greenhouse gases in the past and present (Andreae et al., 2005; Andreae, 2007; Carslaw et al., 2013; Gordon et al., 2016, 2017). Moreover, the largest uncertainty with respect to global radiative forcing emerges from knowledge gaps related to interactions between aerosols and clouds, as highlighted within IPCC (Intergovernmental Panel on Climate Change) assessment reports (IPCC, 2014). Although some recent studies indicate that urban-pollution aerosol does not make efficient INPs (e.g., Chen et al., 2018), the overall anthropogenic impact on the INP concentration is still rather inconclusive (see also Schrod et al., 2020a). Given the poor understanding of INP climatology and life cycles, it is not surprising that the magnitude and effects of a potential anthropogenic INP perturbation cannot yet be assessed (Boucher et al., 2013; IPCC Fifth Assessment Report - AR5, Sect. 7). Similarly, in a review of the state of knowledge on pre-industrial aerosols Carslaw et al. (2017) were unable to comprehensively discuss the matter due to a lack of thorough understanding regarding which aerosol components dominate the INP spectra. They argue that the concentrations of INPs, which tend to be large particles, likely have not changed as much as those of smaller particles, which have been found to be significantly altered since the pre-industrial era (Hamilton, 2015; Gordon et al., 2017). Nonetheless, Carslaw et al. (2017) acknowledge that potential anthropogenic modifications to INP concentrations or compositions and related impacts on cloud formation, radiation interactions and precipitation processes since the industrialization remain unquantified.

Here we present long-term measurement data of INPs from a small but unique network of stations spanning over $80^{\circ}$ in latitude. Observational sites were located within vastly contrasting climates and ecosystems, featuring continental tropical, marine subtropical, continental midlatitude and Arctic mountaintop locations. The sites are exposed to varying and seasonally different degrees of anthropogenic influence; yet all can be classified as rural, remote and/or pristine environments for at least parts of the year. However, truly pristine regions, which still resemble their pre-industrial state in all facets, may be hard to find on an increasingly polluted planet (Hamilton et al., 2014). For this study, INPs were sampled at the Amazon Tall Tower Observatory (Brazil; $2.144^{\circ} \mathrm{S}, 59.000^{\circ} \mathrm{W}$; Fig. S1 in the Supplement), the Volcanological and Seismological Observatory of Martinique (Caribbean Sea; $14.735^{\circ} \mathrm{N}, 61.147^{\circ} \mathrm{W}$; Fig. S2), the Taunus Observatory (Germany; $50.221^{\circ} \mathrm{N}, 8.446^{\circ} \mathrm{E}$; Fig. S3) and the Zeppelin Observatory (Norwegian Arctic; $78.908^{\circ} \mathrm{N}$, $11.881^{\circ}$ E; Fig. S4).

Between May 2015 and January 2017 a total of 1212 aerosol samples (7704 data points) were collected and analyzed for INPs in the deposition and condensation freezing modes (Fig. 1). Aerosol samples were collected using electrostatic precipitation on silicon substrates in a semiautomated routine. Samples were shipped to our laboratory in Frankfurt and were subsequently analyzed for ice nucleation activity using the FRIDGE isothermal vacuum diffusion chamber (Schrod et al., 2016, 2017). Each sample was analyzed at multiple combinations of temperature $(-20,-25$ and $\left.-30{ }^{\circ} \mathrm{C}\right)$ and relative humidity $(95 \%, 97 \%, 99 \%$ and $101 \%$ with respect to water).

The main objectives of this study were to (1) observe the long-term concentrations and variability of INPs, (2) investigate potential trends and/or seasonalities, (3) compare the INP concentrations of diverse geographic locations, (4) estimate the anthropogenic impact on INPs at semi-pristine sites, and (5) try to identify what factors control ice nucleation in the atmosphere.

\section{Methods}

\subsection{FRIDGE operational modes}

The FRIDGE (Frankfurt Ice Deposition Freezing Experiment) instrument was originally introduced by Bundke et al. (2008) and Klein et al. (2010) but was fundamentally reevaluated and updated by Schrod et al. (2016). Since this effort FRIDGE has participated in laboratory intercomparisons (Hiranuma et al., 2015; DeMott et al., 2018; Hiranuma et al., 2019) and field campaigns (Schrod et al., 2017; Thomson et al., 2018; Gute et al., 2019; Marinou et al., 2019). In its original design FRIDGE serves as an isothermal static diffusion chamber for offline analysis of ice nucleation. In this standard operation mode FRIDGE analyzes deposition and condensation, freezing INPs on substrates that had been laden with atmospheric aerosol particles by electrostatic precipitation. To avoid confusion, we point out that the FRIDGE instrument can in fact be modified to serve as a cold stage for droplet-freezing assay measurements as well, which was, however, not done for the results presented here.

\subsection{Aerosol sampling}

In all locations aerosol samples were collected using the Programmable Electrostatic Aerosol Collector (PEAC7, Schrod et al., 2016). PEAC7 precipitates aerosol particles which have been charged by collision with corona-discharge electrons electrostatically onto a semi-conducting grounded sample substrate made from commercially available silicon wafers. The $45 \mathrm{~mm}$ diameter substrates have three laserengraved crosses used to generate a coordinate system that allows ice crystals and thus particles to be located in the INP counter FRIDGE (Sect. 2.3). Electrostatic precipitation is advantageous compared to simple impaction, as particles are distributed more homogeneously across the surface. Thereby, FRIDGE is able to activate and count up to about 1000 separate ice crystals simultaneously on one sample substrate. The PEAC7 collection efficiency has been found to be about 
(a)

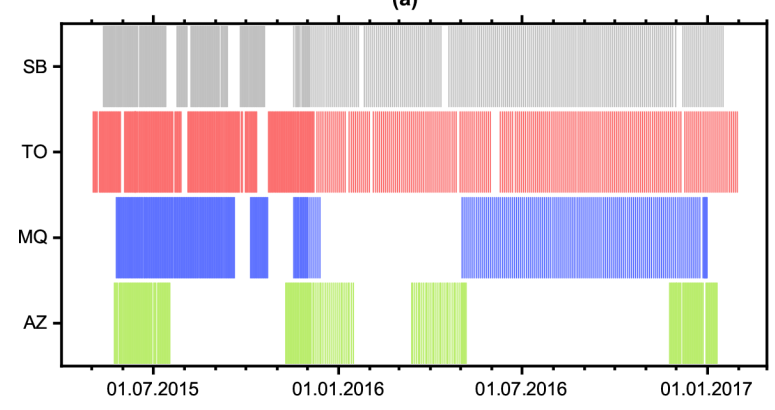

(b)

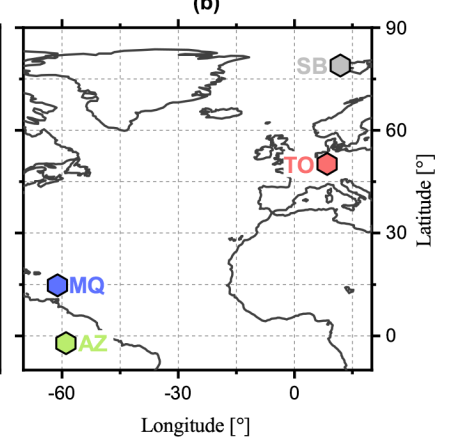

Figure 1. Sampling days at the four stations (a) and their corresponding geographic location (b). Line thickness indicates the sampling frequency (thick connected lines: daily; thin non-connected lines: one sample every $2 \mathrm{~d}$ ).

$60 \%$, independent of particle size (Schrod et al., 2016). Accordingly, a correction factor of 0.6 has been applied to the data. No inlet size cutoffs were used for the results presented here, and thus we expect to sample the complete particle spectrum, except for the usual particle losses that may occur for large particle sizes. The exact aerosol inlet configuration differed substantially between sites and was mainly predetermined by the local observatory facilities. Unfortunately, these inconsistencies may lead to some aerosol sampling artifacts with respect to the absolute particle losses. The individual sampling configurations are described in Sect. 2.4 and Table 1.

PEAC7 utilizes a step-motor-powered rotary disc with seven sample substrate slots for programmed sampling. When connected to a PC with an internet connection, PEAC7 can be programmed either directly or remotely to start and stop sampling at prescribed times. This configuration enables daily sampling for 1 week with minimal service and maintenance. Combined with the ease of operation, this makes PEAC7 a well-suited instrument to collect aerosol particles at multiple field sites for subsequent offline INP analysis.

A PEAC7 unit was first installed in 2012 at the Kleiner Feldberg Observatory of the Goethe University of Frankfurt. PEAC7 units were deployed at the other three sites during the summer and fall of 2014. The local staff of each observatory conducted the regular measurements and maintenance after being trained in the handling of the instrument. Concurrent sampling began in May 2015 and continued (with some interruptions) until January 2017 for the three overseas stations. The measurements at Taunus Observatory began earlier and continued longer, but here we focus on the concurrent sampling effort conducted within the framework of the EU FP7 BACCHUS (Impact of Biogenic versus Anthropogenic emissions on Clouds and Climate: towards a Holistic UnderStanding; European Union Seventh Framework Programme) project (Fig. 1). Due to the failure of the complementary aerosol instrumentation at the Caribbean site, sampling was interrupted between December 2015 and May 2016. Furthermore, the exchange of sampling substrates with the Amazonian site was logistically challenging. Thus, the Amazon data set is represented by several shorter periods of continuous measurements. Between October 2015 and February 2016 some unexplained contamination in the process of wafer cleaning prevented cleaning substrates to below the desired background level of INP at the lowest temperature. As a consequence no data below $-25^{\circ} \mathrm{C}$ are available for this period.

Typically, aerosol samples were collected with PEAC7 daily or once every 2 days at local noon. Sampling time was prescribed to $50 \mathrm{~min}$ with a $2 \mathrm{~L} \mathrm{~min}^{-1}$ flow rate. The sampled aerosol particles resulting from this $100 \mathrm{~L}$ of air were found to usually generate well-resolved ice crystal numbers in the investigated temperature regime using the FRIDGE analysis system. However, the level of representativeness of the deployed sampling strategy is difficult to assess (see discussion). Yet, the pursued sampling protocol ensured a consistent database. Samples were then stored in PetriSlide containers after collection until they were shipped unfrozen in packages of 25-50 to our laboratory in Frankfurt (transport time was usually less than a week). As a result, several weeks often passed between sample collection and analysis, which may introduce an aging effect. However, in a previous study no effect of storage time on ice nucleation activity was observed within the investigated temperature regime (Schrod et al., 2016). Since a frozen storage and transport could not be logistically guaranteed for all sites and for all times, samples were stored and transported at ambient temperatures, which may have affected the warm end of (biological) INPs.

\subsection{Analysis of ice nucleation samples}

During a FRIDGE measurement the sample substrate is placed on the cold table inside a sealed measurement cell. The temperature of the substrate is controlled by a Peltier element and monitored by a PT- 1000 sensor at the wafer surface. The measurement cell is connected by a valve to a water vapor source. The vapor source vessel is evacuated, except for water vapor from a thin ice film coating the inner walls, which are temperature-controlled by a cryostat (Huber 
Table 1. Main characteristics of the geographic sampling location and inlet configuration at the sites. AZ: Amazon; MQ: Martinique; TO: Taunus; SB: Svalbard.

\begin{tabular}{|c|c|c|c|c|}
\hline & $\mathrm{AZ}$ & MQ & TO & SB \\
\hline Geographic coordinates & $2.144^{\circ} \mathrm{S}, 59.000^{\circ} \mathrm{W}$ & $14.735^{\circ} \mathrm{N}, 61.147^{\circ} \mathrm{W}$ & $50.221^{\circ} \mathrm{N}, 8.446^{\circ} \mathrm{E}$ & $78.908^{\circ} \mathrm{N}, 11.881^{\circ} \mathrm{E}$ \\
\hline Altitude [m a.m.s.l.] & 130 & 487 & 825 & 474 \\
\hline Climate & Tropical & (Sub-)tropical & Temperate & Arctic \\
\hline Continental or marine & Continental & Marine & Continental & Marine \\
\hline Mountain site & No & Yes & Yes & Yes \\
\hline Predominant vegetation & Tropical rainforest & $\begin{array}{l}\text { Diverse (i.e., ranging } \\
\text { from alpine to tropical } \\
\text { rainforest) }\end{array}$ & Coniferous forest & $\begin{array}{l}\text { Low-growing tundra } \\
\text { (summer) or snow- } \\
\text { covered (winter) }\end{array}$ \\
\hline Anthropogenic impact & Near pristine to polluted & Remote to polluted & Rural to polluted & $\begin{array}{l}\text { Near pristine to pol- } \\
\text { luted }\end{array}$ \\
\hline Inlet type & $\begin{array}{l}\text { Total suspended particulate } \\
\text { (Moran-Zuloaga et al., 2018) }\end{array}$ & $\begin{array}{l}1 / 4^{\prime \prime} \text { tube, rain shield } \\
\text { (no characterized inlet) }\end{array}$ & $\begin{array}{l}\text { HORIBA ASS-370 type } \\
\text { (ÖNORM, 2007) }\end{array}$ & $\begin{array}{l}\text { Whole-air } \\
\text { (Karlsson et al., 2020) }\end{array}$ \\
\hline Inlet height [m a.g.l.] & 60 & 2 & 11 & 7.5 \\
\hline Isokinetic flow splitter & Yes & No & Yes & Yes \\
\hline $\begin{array}{l}\text { Length of tubing to } \\
\text { PEAC7 }[\mathrm{m}]\end{array}$ & 1.5 & 2 & 1 & 2 \\
\hline
\end{tabular}

Petite Fleur). Thus, the temperature of ice film defines the water vapor pressure (Clausius-Clapeyron equation), which is measured by an Edwards Barocel capacitance manometer. The measurement cell is kept at near-vacuum conditions, until a controlled amount of water vapor is introduced as a measurement begins by opening the valve to the vapor source. Ice crystals activate rapidly on the surface of INPs and grow to macroscopic sizes within some tens of seconds. The ice crystals are counted automatically by a CCD (charge-coupled device) camera viewing the measurement from above. After a measurement is completed, the valve to the water vapor source is closed, and the valve to the vacuum pump is opened. Subsequently, ice crystals evaporate, and a new combination of temperature and ice supersaturation can be selected (Table 2). Typical measurement uncertainties are summarized in the caption of Table 4. A complete description of the method can be found in Schrod et al. (2016).

One of the main strengths of FRIDGE is the direct visual observation of the ice crystal formation on the surface of the sample substrate. No complicated data analysis is required to establish the number of INPs. Furthermore, knowing the exact location of a specific ice crystal allows for a subsequent electron microscopy analysis to determine the chemical composition and morphology of individual INPs. We refer to our previous study for methodological details about coupling FRIDGE to an scanning electron microscope (Schrod et al., 2017).
Table 2. Thermodynamic conditions for INP analysis in FRIDGE. Conditions were selected in order to steadily progress from lower to higher $\mathrm{RH}_{\text {ice }}$ with the respective highest and lowest supersaturations overlapping at each temperature increment.

\begin{tabular}{lrr}
\hline$T\left[{ }^{\circ} \mathrm{C}\right]$ & $\mathrm{RH}_{\text {water }}[\%]$ & $\mathrm{RH}_{\text {ice }}[\%]$ \\
\hline-20 & 95 & 115.6 \\
& 97 & 118.0 \\
& 99 & 120.4 \\
& 101 & 122.9 \\
\hline-25 & 95 & 121.3 \\
& 97 & 123.9 \\
& 99 & 126.4 \\
& 101 & 129.0 \\
\hline-30 & 95 & 127.4 \\
& 97 & 130.1 \\
& 99 & 132.7 \\
& 101 & 135.4 \\
\hline
\end{tabular}

\section{Freezing modes}

It should be noted that we cannot predict how our deposition and condensation freezing measurements would translate to the immersion freezing mode in a situation given in the atmosphere. Some conclusions may however be drawn from previous parallel measurements (for FIN-03 and CLACE, Daniel Weber, unpublished data, 2019; for PICNIC, Sarah Richter, unpublished data, 2020) with the FRIDGE diffu- 
sion chamber and the FRIDGE droplet-freezing assay in different environments during the FIN-03 (The Fifth International Workshop on Ice Nucleation phase 3; Storm Peak Laboratory, SPL, USA, 2015), CLACE-INUIT (Cloud and Aerosol Characterization Experiment-Ice Nuclei Research Unit; Jungfraujoch, JFJ, Switzerland, 2017) and PICNIC (Puy de Dôme Ice Nucleation Intercomparison Campaign; Puy de Dôme, PDD, France, 2018) campaigns. Daily average INP concentrations (i.e., one daytime sample and one nighttime sample) covered three orders of magnitude at $-25^{\circ} \mathrm{C}$. When transforming the INP concentrations to log space, we find that the two operational modes are well correlated ( $R=0.81, N=44)$, with the immersion freezing INPs being on average a factor of 10 higher than deposition and condensation INPs. In fact, the INP concentrations measured in the droplet-freezing assay were always higher. One may speculate that both species simply covary for the reason of having the same sources and sinks or that deposition INPs may represent just a subset of immersion INPs when observed by FRIDGE or both. We will present the results of this comparison in more detail in a forthcoming publication, in which we will further investigate how exactly the nucleation modes of both methods are connected to each other.

Except when noted otherwise, the discussion presented in Sect. 3 will focus on the highest ice supersaturation(s) $\mathrm{RH}_{\text {ice }}$ at each of the three examined activation temperatures (Table 2). At these highest saturation conditions, at or slightly above water saturation, we observe the highest INP concentrations. We expect the nucleation mechanism to be a mixture of deposition nucleation and condensation freezing. At lower supersaturations we qualitatively observe trends and variability in INPs that are similar but at lower absolute concentration levels.

\subsection{Measurement sites}

\subsubsection{Amazon Tall Tower Observatory - AZ}

The Amazon Tall Tower Observatory (ATTO; $2.144^{\circ} \mathrm{S}$, $59.000^{\circ} \mathrm{W}, 130 \mathrm{~m}$ a.m.s.l.) was established to investigate atmosphere-biosphere interactions and for observing longterm changes in the Amazonian environment. The ATTO site is located about $150 \mathrm{~km}$ northeast of Manaus, Brazil. Atmospheric measurements have been conducted here since 2012, when two $80 \mathrm{~m}$ towers were constructed. The main ATTO tower (325 m) was finished in 2015.

The Amazon basin contains the largest rainforest in the world and thus has great importance for global and regional carbon and water cycles and biodiversity. Although the "green ocean" is unparalleled in size, distinct changes in the water and energy budgets of the Amazon basin are becoming apparent due to anthropogenic impacts such as agricultural expansion, deforestation and climate change (Davidson et al., 2012). According to Davidson et al. (2012) the Amazon basin is already in transition, and it is therefore important to monitor changes and their related effects on the biosphere and the atmosphere. Andreae et al. (2015) present a detailed description of the site characteristics and provide an overview of the vast array of ecological, meteorological, trace gas and aerosol measurements at ATTO. Pöhlker et al. (2019) expanded upon the general site characterization by presenting a comprehensive analysis of the backward-trajectory footprint region for the ATTO site and included an in-depth discussion about land cover transformations. Back trajectories differ significantly between the wet season (February to May: northeast) and the dry season (August to November: southeast). There is also a distinct seasonality in pollution markers measured at the site (Saturno et al., 2018; Holanda et al., 2020). During the dry season biomass burning heavily influences the site, resulting in an order of magnitude increase in aerosol number concentration. Pöhlker et al. (2016) conducted size segregated CCN (cloud condensation nuclei) measurements that provide near-continuous coverage of a complete seasonal cycle. They found a pronounced CCN seasonality that covaries with both aerosol number concentration and pollution markers. However, during the wet season aerosol conditions remain largely unaffected by pollution and are considered to be comparatively clean. According to Pöhlker et al. (2018) there are typically 10 to $40 \mathrm{~d}$ from March to May which can be considered as pristine. During both the dry and wet season (and especially in February and March) plumes of long-range transported aerosol are relatively frequent. These aerosols include Saharan dust (mainly wet season), particles from biomass burning in Africa and sea salt from the Atlantic Ocean. During such episodes of long-range transport, coarsemode particle concentrations may rise above $100 \mu \mathrm{g} \mathrm{m}^{-3}$, altering the aerosol size spectrum and composition substantially (Moran-Zuloaga et al., 2018). Except for these singular events, coarse-mode particle concentrations remain fairly constant throughout the year, showing only a weak seasonality. In the absence of long-range transport, primary biological aerosol particles (PBAPs) dominate the coarse-mode population. It is important to note here, however, that PBAPs peak during the nighttime in Amazonia. At local noon, when the samples were collected, concentrations of PBAPs are typically a factor of 2-5 lower (Huffman et al., 2012).

The INP sampling device PEAC7 was installed inside a container at the base of one of the smaller $80 \mathrm{~m}$ towers. Ambient air was introduced to PEAC7 through a $25 \mathrm{~mm}$ stainless steel line, connected to a total suspended particle inlet at $60 \mathrm{~m}$ a.g.l. (i.e., $30 \mathrm{~m}$ above canopy height). Moran-Zuloaga et al. (2018) show that losses of particles $<2 \mu \mathrm{m}$ at realistic particle densities are usually well below $10 \%$ for this setup and that the transmission efficiency only drops below $50 \%$ for particles larger than $6 \mu \mathrm{m}$ and a high particle density of $2 \mathrm{~g} \mathrm{~cm}^{-3}$. An extensive inlet characterization can be found in the Supplement of Moran-Zuloaga et al. (2018).

INP measurements from this site are labeled with the abbreviation AZ. 


\subsubsection{Volcanological and Seismological Observatory of Martinique - MQ}

The Volcanological and Seismological Observatory of Martinique (OVSM; $14.735^{\circ} \mathrm{N}, 61.147^{\circ} \mathrm{W}, 487 \mathrm{~m}$ a.m.s.l.) is located on the Morne des Cadets mountaintop in northwestern Martinique, which is an island in the Lesser Antilles in the Caribbean Sea. The observatory, in its current form, was built in 1937 after scientific interest increased following a devastating volcanic eruption of the nearby Mt. Pelée in 1902 and a second period of activity from 1929 to 1932 . The observatory is operated by the Institut de Physique du Globe de Paris and closely monitors the local volcanic and regional seismic activity.

About two-thirds of Martinique is protected by regional natural parks to preserve the island's environment. A regional park completely surrounds the observatory and encompasses the majority of northwestern Martinique, which contains large areas that are labeled as natural zones of major interest (PNRM, 2020). The observatory is about $15 \mathrm{~km}$ north of the capital Fort-de-France and about $20 \mathrm{~km}$ northwest of the island's airport. Eastern trade winds are dominant, and air masses reaching the site are primarily of maritime origin. Thus, we find it unlikely that our measurements of INPs are significantly influenced by local pollution.

Similar to the Amazonian site, the Caribbean site is also subject to a seasonality in precipitation and atmospheric transport patterns due to the migration of the Intertropical Convergence Zone (ITCZ). The dry season begins in December and ends in May; the wet season lasts from June to November.

Stevens et al. (2016) analyzed 2 years of daily $10 \mathrm{~d}$ back trajectories arriving at $3 \mathrm{~km}$ over Barbados. Qualitatively, this analysis should also be representative of the large-scale transport pattern to Martinique, which is only $200 \mathrm{~km}$ northwest of Barbados. It was found that the majority of air masses originated north of $10^{\circ} \mathrm{N}$ and east of $55^{\circ} \mathrm{W}$. Approximately half of the air masses traveled from this direction during the dry season and about two-thirds during the wet season, respectively. During the dry season $8 \%$ of these air masses are influenced by the European or African continent(s), and $55 \%$ are influence during the wet season. Accordingly, seasonal wind shifts regulate the amount of long-range transported aerosol arriving in the Caribbean. The maximum contribution of Saharan mineral dust over the Lesser Antilles is found in the Northern Hemisphere (NH) summer. Yet, the interactions between dust and precipitation introduce considerable variability in aerosol optical depth (AOD) during the wet season (Stevens et al., 2016). Some "clean periods" with AOD below 0.01 were observed, despite the generally heavy dust load during the wet season. In the dry season the amount of dust reaching the Caribbean is reduced considerably. The long-term trends, variation and seasonality of mineral dust transported to the Caribbean have been monitored almost continuously since 1965 (Prospero and Lamb, 2003). The
Lesser Antilles' location at the end of the transatlantic trade wind flow and the well-characterized dust fraction make it an excellent place to investigate the influence of mineral dust on cloud formation.

Sea salt makes up most of the remaining mass fraction of Caribbean aerosol. The mass concentration of sea salt is typically of the same order of magnitude as mineral dust, yet its seasonality is different (Stevens et al., 2016). Due to higher wet scavenging and slower wind speeds from June to November, the sea salt contribution is at a minimum during the wet season and a maximum during the dry season.

To date few investigations of atmospheric aerosol and cloud formation have been conducted in the Lesser Antilles, and none have been conducted at OVSM. In 2011 the extensive field campaign DOMEX-2011 (Dominica Experiment), which focused on the formation of orographic clouds and related precipitation events, was based from Dominica, the island just to the north of Martinique (Smith et al., 2012). The DOMEX campaign, which included several research flights, found that the clouds and precipitation were strongly sensitive to trade wind speeds and therefore local dynamics and convection. In that campaign INPs were not considered as an important variable or driver of clouds and precipitation.

Prior to the initiation of the PEAC7 sampling in September 2014, OVSM was not equipped with aerosol instrumentation. Therefore, a TSI OPS 3330 (optical particle diameter: $0.3-10 \mu \mathrm{m}$ ) was installed to complement the PEAC7 measurements. Both instruments were connected to a $2 \mathrm{~m}$ stainless steel line, mounted on the north side of the building. The inlet was open to freely circulating air coming from the west, north and east (main wind direction) and was protected from precipitation and spray water by a custom-made lid.

INP measurements from this site are labeled with the abbreviation MQ.

\subsubsection{Taunus Observatory - TO}

The Taunus Observatory (TO; $\left.50.221^{\circ} \mathrm{N}, 8.446^{\circ} \mathrm{E}\right)$ is located on top of Kleiner Feldberg ( $825 \mathrm{~m}$ a.m.s.l.) within the Taunus highlands of central Germany. There are several mountain peaks of similar height in the immediate vicinity (e.g., Großer Feldberg at $878 \mathrm{~m}$ a.m.s.l. and Altkönig at $798 \mathrm{~m}$ a.m.s.l.). The Taunus mountains are nearly completely forested, predominantly with coniferous trees. Sobanski et al. (2016) described the land cover of the area surrounding the Kleiner Feldberg and found that about $80 \%$ of the area within $5 \mathrm{~km}$ is covered by forest. Within $50 \mathrm{~km}$ about onethird of the area is forested, while agriculture makes up another $40 \%$, and urban areas make up about $10 \%$. The Taunus mountain range extends about $70 \mathrm{~km}$ from the Rhine river to the northeast and serves as a natural barrier to the RhineMain metropolitan region, with its center located to the south of the range. The Rhine-Main metropolitan region is heavily industrialized and densely populated, with about 2.2 million people living in and around the city of Frankfurt. The city 
lies about $20 \mathrm{~km}$ southeast of the Taunus Observatory. At the southwestern end of Frankfurt is the industrial area Höchst, which is one of the largest chemical and pharmaceutical industrial sites in Europe. The Frankfurt airport is also roughly $20 \mathrm{~km}$ to the south of the observatory. The cities of Wiesbaden and Mainz are also located $20-30 \mathrm{~km}$ to the southwest. In contrast, the northern sector is sparsely populated and predominantly devoid of industrial influence for 50 to $100 \mathrm{~km}$.

Pollutant data, measured routinely by the Hessian Agency for Nature Conservation, Environment and Geology (HLNUG, 2020) using a HORIBA APNA-370 (NO and $\left.\mathrm{NO}_{2}\right)$, a HORIBA APOA-370 $\left(\mathrm{O}_{3}\right)$ and DIGITEL DHA-80 $\left(\mathrm{PM}_{10}\right)$, have been analyzed for TO for the years 2015 to 2017, in order to quantify the predominant direction of the anthropogenic influence; 30 min mean concentrations of pollutants have been divided into wind sectors and are presented in Table 3. As expected, pollutant concentrations are significantly higher when originating from the metropolitan sector, compared to air coming from other directions. However, as can be seen in Table 3 the site is rarely downwind from the highest pollution sources. In fact, the main wind direction is west. Thus generally, the site may be categorized as primarily rural with anthropogenic impacts.

Samples were collected from the upper level of Atmospheric Physics Laboratory at the hilltop. The aerosol inlet was at $11 \mathrm{~m}$ above ground. A main flow of ambient air was pumped through a HORIBA ASS-370 type inlet (ÖNORM, 2007) with a $40 \mathrm{~mm}$ I.D. $\times 7 \mathrm{~m}$ length stainless steel tube into the laboratory. The PEAC7 collected aerosol isokinetically at $2 \mathrm{~L} \mathrm{~min}^{-1}$ from the main flow through a nozzle of $2.2 \mathrm{~mm}$ diameter.

INP measurements from this site are labeled with the abbreviation TO.

\subsubsection{Zeppelin Observatory - SB}

The Zeppelin Observatory, operated by the Norwegian Polar Institute, is located on Mt. Zeppelin close to Ny-Ålesund in Svalbard (78.908 ${ }^{\circ} \mathrm{N}, 11.881^{\circ} \mathrm{E}, 474 \mathrm{~m}$ a.m.s.l.). Svalbard, and Ny-Ålesund in particular, is a well-established site for Arctic and atmospheric research. The scientific focus of the observatory is to characterize the Arctic atmosphere and identify relevant atmospheric processes in a changing Arctic climate. The mountain top Zeppelin Observatory was chosen for its elevated position, which likely limited the effects of locally produced pollution and of sea spray from the surf zone. However, the observatory largely remains within the planetary boundary layer (Tunved et al., 2013). The station is representative of the remote Arctic, making it a unique location to study atmospheric aerosol. A variety of trace gases, greenhouse gases, aerosol particles, heavy metals and other compounds are monitored continuously at Zeppelin. A whole air inlet was used for aerosol particle sampling according to the ACTRIS (Aerosol, Clouds, and Trace Gases Research InfraStructure) guideline for stations that are often embedded in clouds. The flow through the inlet was kept constant to ensure near-isokinetic sampling conditions. A short description about the inlet characteristics of the Zeppelin Observatory can be found in Karlsson et al. (2020).

Tunved et al. (2013) calculated a monthly climatology of air masses arriving at Mt. Zeppelin between 2000 and 2010. They observed two primary transport patterns: for most of the year trajectories predominantly originated from Siberia and Eurasia. These air masses are mainly transported over the Arctic Ocean before arriving at Svalbard. During the summer months Atlantic air masses arriving from the southwest are most frequent. Although the Arctic is generally associated with clean atmospheric conditions, there are times of the year when contaminants are transported to the Arctic, leading to a significant decrease of air quality. This so-called Arctic haze phenomenon has been long known and is well studied. The Arctic haze occurs during late winter and spring when air is transported from industrialized source regions in Eurasia and North America. Tunved et al. (2013) observed the aerosol mass concentration over a period of 10 years at Zeppelin Observatory and confirmed an annually repeating Arctic haze signal with a maximum in spring. Long-term black carbon measurements at Zeppelin show virtually the same seasonal pattern (Eleftheriadis et al., 2009). Cruise ships have been identified as an additional important local source at Zeppelin (Eckhardt et al., 2013). In a generally clean environment this might be of importance to INPs, as ship emissions have previously been observed to amplify INPs (Thomson et al., 2018). Weinbruch et al. (2012) analyzed over 50000 individual particles in 27 aerosol samples collected between summer 2007 and winter 2008 at Mt. Zeppelin by electron microscopy. Potential INP-related particles, i.e., particles with a diameter larger than $0.5 \mu \mathrm{m}$, were mainly categorized as sea salt, aged sea salt, silicates or mixed particles (i.e., mixtures of sea salt, silicates and calcium sulfates). Mineral dust particles were found to follow a seasonal pattern with a summer minimum.

INP measurements from this site are labeled with the abbreviation SB.

\section{Results and discussion}

\subsection{Concentrations, variations, trends and seasonality of INPs}

The INP concentrations from May 2015 to January 2017 at the four stations at $-20,-25$ and $-30^{\circ} \mathrm{C}$ are presented in Figs. 2, 3 and 4. Key statistical parameters of the data set are summarized in Table 4 . The most striking result from the time series is that the deposition and condensation freezing INP concentrations do not fundamentally differ from station to station. We find that average INP concentrations at the examined temperatures are of the same order of magnitude for all sites. This observation is somewhat surprising, since the 
Table 3. Air quality data at Taunus Observatory as a function of local wind direction: average values of major pollutants measured between 2015 and 2017 (HLNUG, 2020).

\begin{tabular}{lrrrrrr}
\hline Region & $\begin{array}{r}\text { Wind sector } \\
{\left[{ }^{\circ}\right]}\end{array}$ & Relative frequency & $\begin{array}{r}\mathrm{NO} \\
{\left[\mu \mathrm{g} \mathrm{m}^{-3}\right]}\end{array}$ & $\begin{array}{r}\mathrm{NO}_{2} \\
{\left[\mu \mathrm{g} \mathrm{m}^{-3}\right]}\end{array}$ & $\begin{array}{r}\mathrm{O}_{3} \\
{\left[\mu \mathrm{g} \mathrm{m}^{-3}\right]}\end{array}$ & $\begin{array}{r}\mathrm{PM}_{10} \\
{\left[\mu \mathrm{g} \mathrm{m}^{-3}\right]}\end{array}$ \\
\hline Frankfurt & $110-140$ & $6 \%$ & 0.73 & 8.17 & 78.30 & 12.36 \\
Airport-autobahn interchange & $150-170$ & $3 \%$ & 1.08 & 11.67 & 78.64 & 11.23 \\
Wiesbaden-Mainz & $200-230$ & $12 \%$ & 0.68 & 8.06 & 67.44 & 8.02 \\
Total Rhine-Main area & $110-230$ & $29 \%$ & 0.78 & 9.26 & 72.79 & 9.87 \\
Not Rhine-Main (rural) & $0-110 ; 230-359$ & $71 \%$ & 0.61 & 6.42 & 67.35 & 8.93 \\
All sectors & $0-359$ & $100 \%$ & 0.66 & 7.25 & 68.96 & 9.21 \\
\hline
\end{tabular}

sites represent drastically different environments. It seems that the climate- and ecosystem-defining characteristics, like the geography of maritime vs. continental locations, Arctic vs. temperate vs. tropical systems and the altitude within the planetary boundary layer, are not overly critical to INP abundance. Instead, it appears as though these differences are mostly lost in the large variability of the INP concentrations. Figure 5 shows the day-to-day variability of the time series. The magnitude of the short-term variability is often almost as high as the total variability of the complete data set, which is represented as the standard deviation in the figure. Overall, short-term variability far outweighed any long-term trend or seasonality at any location or temperature. In fact, mean INP concentrations remained remarkably constant throughout the investigated time period, which is apparent from the 10-point moving averages in Figs. 2, 3 and 4. Moreover, the lack of well-defined peak INP concentrations is evident (on the logarithmic scale). These findings are remarkable considering that the climatic and geographical features of the sites are accompanied by vastly dissimilar air mass transport patterns, aerosol source locations and levels of anthropogenic impact. However, it should be noted here that the collected data represent single $50 \mathrm{~min}$ sampling intervals at local noon with a frequency of 0.5 to 1 sample $\mathrm{d}^{-1}$. The level to which the sampling strategy may implicitly result in the observed high short-term variability is uncertain and should be carefully explored. Comparisons with other recently published data sets suggest that long-term trends may be better captured using different sampling strategies (Schneider et al., 2020). The authors of that study observe a clear seasonal cycle of (biological) immersion INPs in a boreal forest using 24-144 h filter sampling at $11 \mathrm{~L} \mathrm{~min}^{-1}$, which is a much longer sampling period than has been used here. Thus it remains an open challenge for the INP community to establish robust measurement protocols for monitoring efforts. Moreover, we cannot entirely exclude the possibility that storage effects may have dampened the trends of the INP concentrations to some degree. Furthermore, differences between the inlet configurations of the individual sites may have influenced the particle sampling process (see Sect. 2.2).
On average, INP concentrations were lowest at SB, which is what can be expected for an Arctic environment. Yet, mean INP concentrations at the other stations were only higher by a factor of $2-4$ at $-30^{\circ} \mathrm{C}$, with those at MQ being the greatest. Especially during the summer of 2015 MQ concentrations were relatively high. However, at the warmest temperature $\left(-20^{\circ} \mathrm{C}\right)$, the highest INP concentrations are measured at TO. In addition, there are fewer samples below the detection limit or the significance level at $-20^{\circ} \mathrm{C}$ at $\mathrm{TO}$. Because the site is surrounded by forests, this might point to a local source of biological INPs, which are known to activate at warmer temperatures. For example, O'Sullivan et al. (2018) found that immersion INP concentrations at $-20^{\circ} \mathrm{C}$ at a northwestern European site were reduced by more than a factor of 2 in $59 \%$ of the cases when samples were heated to $100^{\circ} \mathrm{C}$. For warmer temperatures the reduction was found to be significantly higher.

Decreasing the nucleation temperature by $5^{\circ} \mathrm{C}$ enhances average INP concentrations by a factor of 2.4 to 5.6. However, as seen in Figs. 6 and S4, average INP concentrations depend predominantly on ice supersaturation. Decreasing temperature alone does not significantly enhance INP concentrations in the addressed nucleation mode. Rather, decreasing the temperature by $5{ }^{\circ} \mathrm{C}$ implicitly leads to an increase in $\mathrm{RH}_{\text {ice }}$ by approximately $6 \%$ for our ascribed conditions (Table 2). Thus, if there was any temperature dependence of note in our data, it would appear as a discontinuity in these plots. Figure 6a shows the median INP concentrations for all measured conditions at each site as a function of supersaturation. The figure implies strong exponential correlations between the INP concentrations and the ice supersaturation $\left(R^{2}\right.$ between 0.95 and 0.98$)$. Once more, we see that at TO more active INPs are found at lower supersaturation, i.e., the warmest temperature $\left(-20^{\circ} \mathrm{C}\right)$. At intermediate ice supersaturations INP concentrations at TO, MQ and $\mathrm{AZ}$ are all similar. At the highest $\mathrm{RH}_{\text {ice }}\left(-30^{\circ} \mathrm{C}\right) \mathrm{AZ}$ and MQ INP concentrations are the greatest. The concentrations at $\mathrm{SB}$ are lowest throughout the full RH spectrum, the reason likely being that the site is farthest away from substantial INP sources. Interestingly, the slopes fitted to the measurements from the European TO and SB stations are nearly identical, as are the 


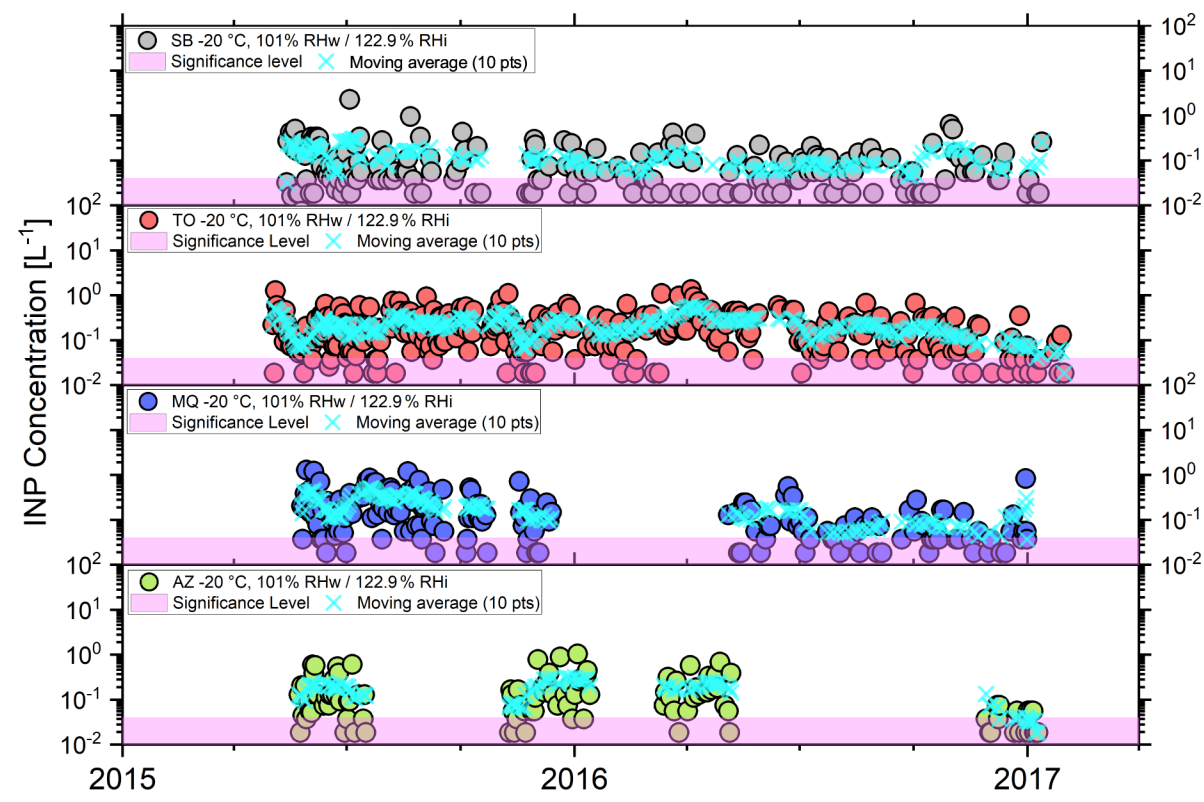

Figure 2. INP concentration at $T=-20^{\circ} \mathrm{C}$ and $\mathrm{RH}_{\mathrm{water}}=101 \%$, which is $\mathrm{RH}_{\mathrm{ice}}=122.9 \%$ (in the figure as $\mathrm{RH}_{\mathrm{w}}$ and $\mathrm{RH}_{\mathrm{i}}$, respectively). The significance level is indicated in pink shading. Cyan crosses are the result of a 10-point moving average for INP concentrations. $x$-axis ticks are shown for 1 January, 1 April, 1 July and 1 October.

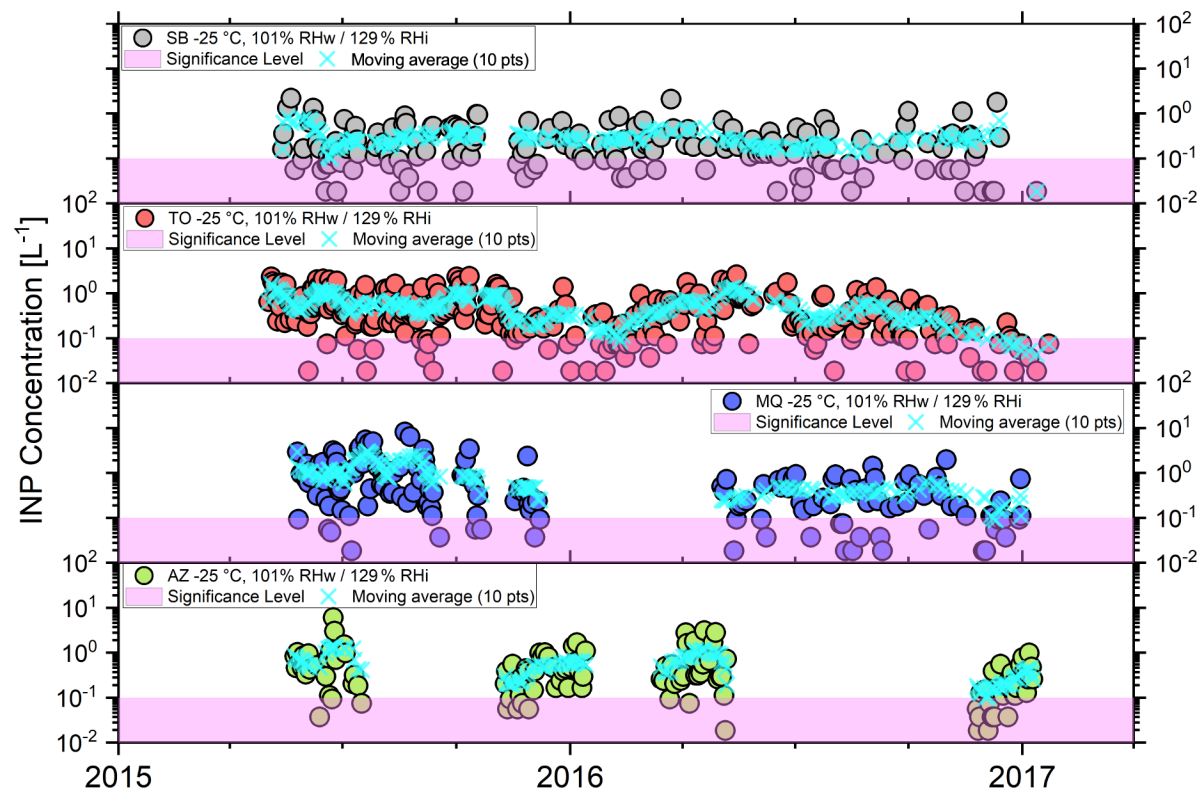

Figure 3. INP concentration at $T=-25^{\circ} \mathrm{C}$ and $\mathrm{RH}_{\text {water }}=101 \%$, which is $\mathrm{RH}_{\text {ice }}=129 \%$. The significance level is indicated in pink shading. Cyan crosses are the result of a 10-point moving average for INP concentrations. $x$-axis ticks are shown for 1 January, 1 April, 1 July and 1 October.

slopes of data from the tropical MQ and AZ stations (Fig. 6a and $b$ ). The differences in the activation spectra may result from different contributions of certain species of INPs at the respective sites. MQ and AZ samples possibly entail a larger fraction of mineral dust compared to TO and SB samples, which may have led to the steeper increase of concentrations. Our view of a generally higher abundance of mineral dust at the low-latitude sites MQ and AZ as compared to the high latitudes of SB and TO is supported by dust observations from surface stations (Prospero, 1996), remote sensing (Kaufman et al., 2005) and models (Zender et al., 2003; Lee et al., 2009). Moreover, median INP concentrations at TO are a factor of approximately 2 higher than SB throughout the spectrum. An increase of $2 \%$ in $\mathrm{RH}_{\text {ice }}$ results in 1.5 (SB 


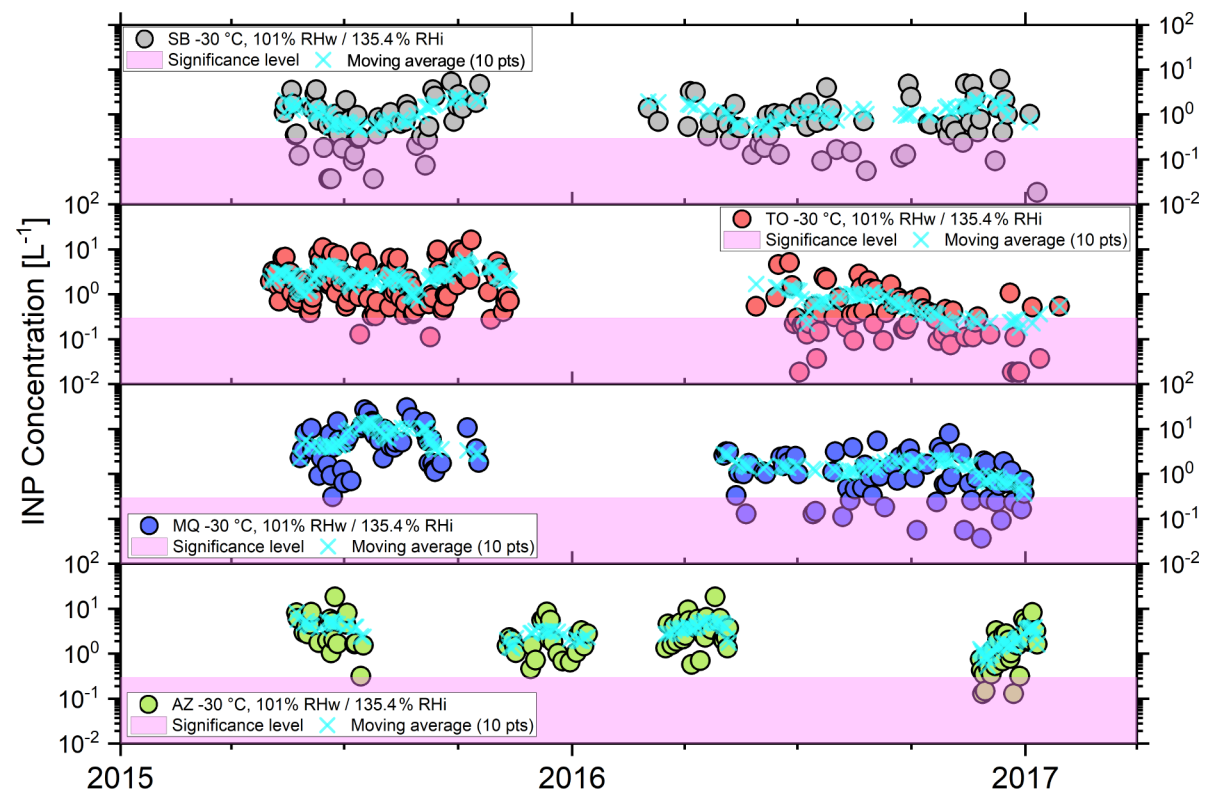

Figure 4. INP concentration at $T=-30^{\circ} \mathrm{C}$ and $\mathrm{RH}_{\text {water }}=101 \%$, which is $\mathrm{RH}_{\text {ice }}=135.4 \%$. The significance level is indicated in pink shading. Cyan crosses are the result of a 10-point moving average for INP concentrations. $x$-axis ticks are shown for 1 January, 1 April, 1 July and 1 October.

Table 4. Statistical parameters extracted from the INP concentrations measured at the four sites. $N_{\text {sig }}$ is the number of samples that had concentrations above the significance level, which was set to twice the background INP concentration. $N_{\text {valid }}$ is the number of valid measurements at this condition, i.e., measurements which were non-zero and above the detection limit. Such measurements typically have an uncertainty of $\mathrm{RH} \pm 2 \%$. Repeated measurements revealed typical uncertainties in the INP concentration on the order of $\pm 30 \%$.

\begin{tabular}{|c|c|c|c|c|c|c|c|c|c|c|c|c|}
\hline & \multicolumn{4}{|c|}{$-20^{\circ} \mathrm{C}, 101 \%$} & \multicolumn{4}{|c|}{$-25^{\circ} \mathrm{C}, 101 \%$} & \multicolumn{4}{|c|}{$-30^{\circ} \mathrm{C}, 101 \%$} \\
\hline & SB & TO & MQ & $\mathrm{AZ}$ & SB & TO & MQ & $\mathrm{AZ}$ & SB & TO & MQ & $\mathrm{AZ}$ \\
\hline $\operatorname{Median}\left[\mathrm{L}^{-1}\right]$ & 0.06 & 0.17 & 0.11 & 0.10 & 0.19 & 0.39 & 0.44 & 0.31 & 0.69 & 1.09 & 1.80 & 2.06 \\
\hline Arithmetic mean $\left[\mathrm{L}^{-1}\right]$ & 0.12 & 0.22 & 0.20 & 0.17 & 0.29 & 0.55 & 0.86 & 0.55 & 1.15 & 2.01 & 4.09 & 3.07 \\
\hline Geometric mean $\left[\mathrm{L}^{-1}\right]$ & 0.07 & 0.14 & 0.11 & 0.10 & 0.17 & 0.32 & 0.38 & 0.30 & 0.64 & 0.99 & 1.79 & 2.03 \\
\hline $\mathrm{SD}\left[\mathrm{L}^{-1}\right]$ & 0.20 & 0.20 & 0.23 & 0.19 & 0.34 & 0.52 & 1.22 & 0.78 & 1.27 & 2.39 & 5.35 & 3.01 \\
\hline$N_{\text {valid }}$ & 186 & 342 & 184 & 110 & 182 & 307 & 164 & 120 & 115 & 194 & 130 & 107 \\
\hline$N_{\text {sig }} / N_{\text {valid }}[\%]$ & 60 & 86 & 77 & 75 & 73 & 83 & 82 & 84 & 78 & 84 & 88 & 97 \\
\hline$N_{\text {valid }} / N_{\text {total }}[\%]$ & 54 & 86 & 65 & 60 & 53 & 77 & 58 & 66 & 33 & 49 & 46 & 59 \\
\hline
\end{tabular}

and TO) to 1.7 (MQ and AZ) times higher INP concentrations. Increasing $\mathrm{RH}_{\text {ice }}$ by $10 \%$ yields 7.4 -fold (SB), 7.6-fold (TO), 12.8-fold (MQ) or 14.7-fold (AZ) changes in INP concentrations. Figure S5 expands upon Fig. 6 by adding more statistical information, such as the arithmetic mean, the interquartile range and the 5\%-95\% range. The findings complement those presented in Fig. 6. Overall, the variability of relative abundance with temperature suggests that the dominant species of INPs do change temporally and between locations. The extent to which changes can be attributed to local vs. more remote INP sources is an interesting question that should be a focus in future studies.

Figure 7 shows the relative frequency distributions of INP concentrations at $-20^{\circ} \mathrm{C}(\mathrm{a}),-25^{\circ} \mathrm{C}(\mathrm{b})$ and $-30^{\circ} \mathrm{C}$ (c).
For the purposes of Fig. 7, samples below the detection limit (or with zero active INPs) or, in a few cases, overloaded samples are excluded. As a result, the distribution tails may be somewhat truncated because the highest and lowest values are not adequately represented. Such an effect is likely more important at $-20{ }^{\circ} \mathrm{C}$ because relatively more samples are below the background detection limit at this temperature. Scaled Gaussian fits in log space are added to emphasize the log-normal nature of the binned frequency distributions that emerge. Welti et al. (2018) analyzed INP data from the subtropical maritime boundary layer and various other marine environments (Welti et al., 2020) in a similar fashion and argued that the observed log-normal nature of the distributions can be explained in an analogous manner to the distributions 

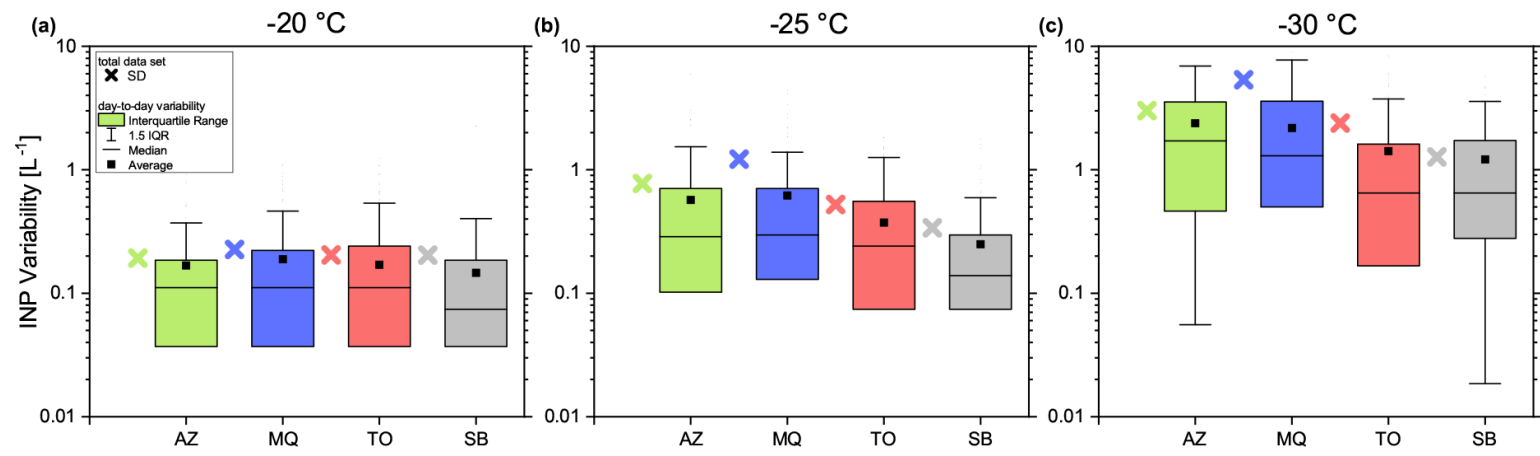

Figure 5. INP variability for $T=-20^{\circ} \mathrm{C}(\mathbf{a}), T=-25^{\circ} \mathrm{C}(\mathbf{b})$ and $T=-30{ }^{\circ} \mathrm{C}(\mathbf{c})$ at $\mathrm{RH}_{\mathrm{water}}=101 \%$. Crosses show the standard deviation of the total data set for each site. Boxplots show the distribution of sample-to-sample differences in the INP concentration of consecutive samples (i.e., day-to-day or every other day). Lower whiskers are not shown when the lower 1.5 interquartile range (IQR) is at zero.
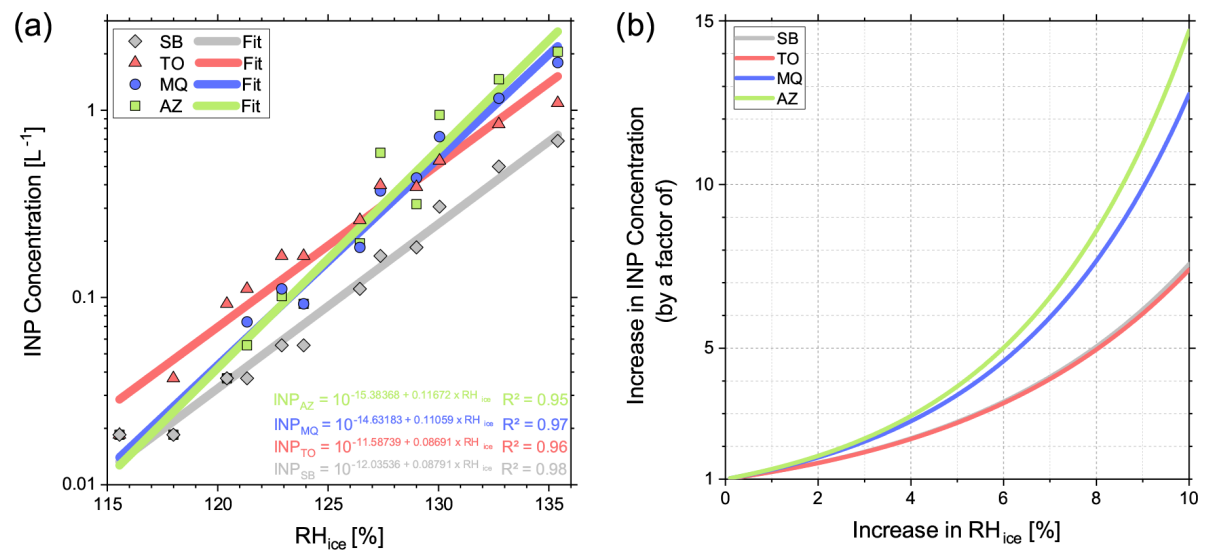

Figure 6. (a) Median INP concentrations at the four sites measured at $T=-20,-25$ and $-30{ }^{\circ} \mathrm{C}$ plotted as a function of $\mathrm{RH}_{\mathrm{ice}}$ according to Table 2. (b) The sensitivity of INP concentrations to increasing ice supersaturation based on the fits shown in (a). Please note that the gray SB curve is largely superimposed by the red curve.

of pollutant species suggested by Ott (1990). The assertion is that for any species of interest (i.e., INPs), many consecutive random dilutions of an air mass containing that species will result in a log-normal distribution of species concentration. Such dilutions will naturally occur during transportation through the atmosphere from the sources to the measurement sites. Variations in source strength are associated with systematic shifts of the whole concentration distribution. For example, when a measurement site is close to a local source, a more left-skewed distribution is to be expected, as a higher proportion of air masses with fewer dilutions will occur. However, the picture that we construct from the INP measurements made at a single point of arrival are convoluted because there is not necessarily one singular source of INPs.

Considering the vastly different geographical locations and environments of the four measurement sites, as well as the inherent variance of atmospheric transportation patterns over time, we do not expect to find simple answers by inspection of the frequency distributions. A few interesting features are, however, apparent, and the log-normal fitting agrees very well with the shape of the INP frequency distributions, which means that the dilution effect may be of importance here. The log-normal shape of the -25 and $-30^{\circ} \mathrm{C}$ distributions is especially evident ( $R^{2}$ ranges from 0.92 to 0.97 ). Here we observe unimodal and regular bell shapes at all four sites. At $-20^{\circ} \mathrm{C}$ the fits are not as good $\left(R^{2}\right.$ ranges from 0.74 to 0.91$)$, and some distributions appear to be potentially bimodal (e.g., $\mathrm{SB})$. However, the strength of the fit may also be related to the fact that at $-20^{\circ} \mathrm{C}$ few ice crystals activate on each sample substrate, introducing a relatively high uncertainty in the INP concentration. Consequently, the incrementation is not ideal for $-20^{\circ} \mathrm{C}$ because measured concentrations are often near the limit of detection and have a poor resolution. This explanation is self-consistent with the observed minimum $R^{2}$ found for $\mathrm{SB}$, where the distribution is heavily skewed to the right. In addition to reflecting the generally low INP concentration of the Arctic environment, this may point to reduced biological activity over much of the year. Interestingly, the shape of the distribution at TO seems to indicate a slight shift towards higher concentrations, pointing to a potential local source of INPs. However, at lower temperatures we do not 

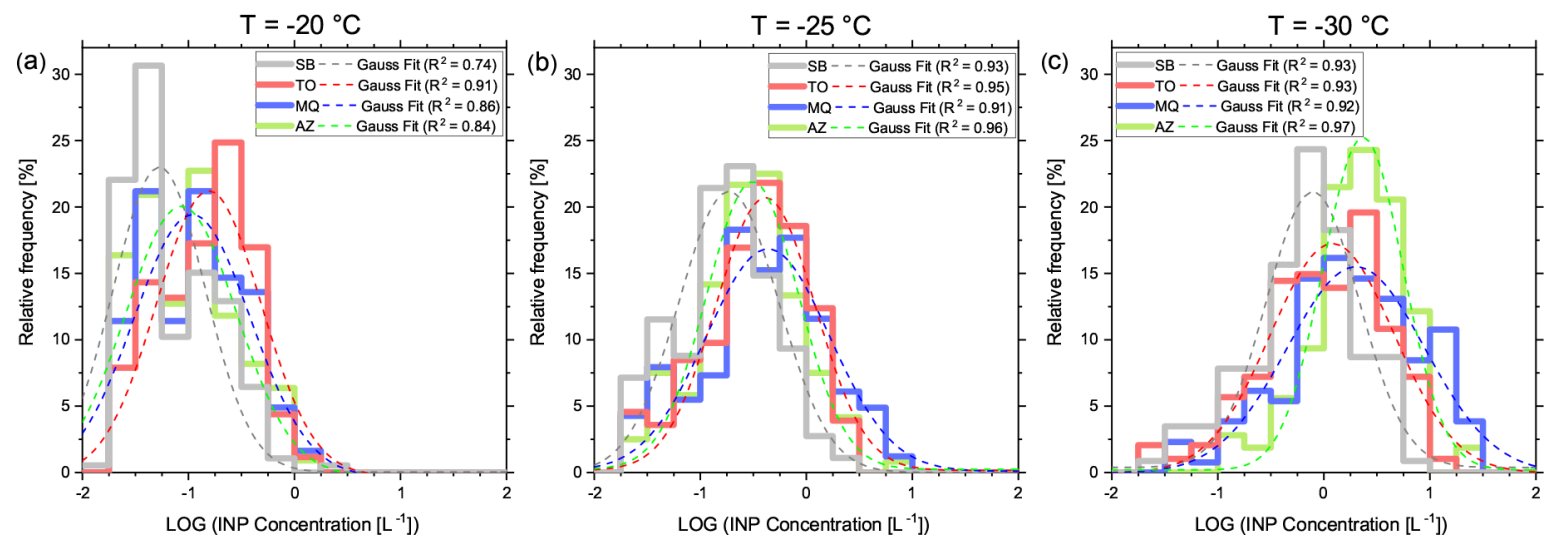

Figure 7. Probability density distribution plots of the INP concentrations at $\mathrm{RH}_{\mathrm{water}}=101 \%$ and $-20^{\circ} \mathrm{C}(\mathbf{a}),-25^{\circ} \mathrm{C}(\mathbf{b})$ and $-30^{\circ} \mathrm{C}(\mathbf{c})$.

find this feature. This could mean that, in addition to whatever long-range transported aerosols contribute to INPs at TO, there might be a biological source from the surrounding forest. However, there is no strong evidence for such a signal in our data overall, possibly due to the comparably low sampling volume. As a result the temperature range of our measurements overlaps only very little with the regime where biological particles nucleate. Remarkably, such a feature seems to be entirely absent from the Amazonian rainforest site, where one would more readily expect to find a local source of primary biological particles that may be potential INPs. On the other hand, surface temperatures never drop below $0{ }^{\circ} \mathrm{C}$ in the Amazon. Therefore, local species of plants or bacteria may be less likely to have evolved traits that induce freezing. It has previously been posited that some microbiology (e.g., bacteria like Pseudomonas syringae) gain an evolutionary advantage by being able to induce freezing (Morris et al., 2014).

At $-25^{\circ} \mathrm{C}$ we find relatively minor differences between the four sites. SB concentrations are slightly shifted to lower concentrations, and the spectrum at MQ concentrations is slightly broader. Differences are more apparent at $-30^{\circ} \mathrm{C}$. Here we find distinctly dissimilar shapes of INP concentration frequency distributions. SB and AZ exhibit narrow peaks relative to the more broad shapes of TO and MQ. The curves are also more distinctly separated in concentration space, with the maximum of the distribution at a minimum concentration for SB, followed by TO, MQ and AZ.

Figure S6 visualizes the information presented in Fig. 7 as function of the relative humidity. The occurrence frequency is color-coded, with cool colors indicating a low and warm colors indicating a high likelihood of this INP concentration at a given saturation condition. Thus Fig. S6 can be understood as follows: a single column (e.g., the rightmost column) gives the full frequency distribution of a single measurement condition (e.g., $135 \% \mathrm{RH}_{\mathrm{ice}}$; corresponds to Fig. 7c). Fewer warm colors appear in a column when the distribution of INP concentrations is broad at that condition.
Conversely, fewer cool tones indicate a narrow distribution. The respective median INP concentration will be close to the maximum of the relative frequency at each condition. Consequently, following the maxima yields information about the steepness of the INP spectra, similar to what is depicted in Fig. 6.

Overall, Figs. 7 and S6 suggest that the INP concentrations measured in the investigated temperature regime at these stations are largely defined by background air masses and that local sources are only of secondary importance. More discussion of the site-specific local sources and characteristic features is provided in the following section.

\subsection{Site-specific INP characteristics}

At each measurement station a diverse array of supplementary meteorological, aerosol and gas data from the stations was collected in parallel to the INP sampling. Unfortunately, the parameters, instrumentation and time coverage vary considerably between the four sites. Observations include typical meteorological parameters such as temperature, relative humidity, precipitation, etc., as well as the total aerosol particle number and mass concentrations, aerosol size distributions, black carbon concentrations, aerosol optical thickness, gaseous pollutant markers, and greenhouse gases. However, despite a rigorous effort including correlation analysis, factor analysis and trajectory sector analysis, we were ultimately unable to identify a single parameter or a set of parameters that account for the total observed variation of INPs. This highlights the complex nature of the ice nucleation process and the particles involved. Whereas similar but somewhat larger-scale long-term measurements of $\mathrm{CCN}$ are able to largely explain the corresponding variability and provide closure studies (Schmale et al., 2018), unfortunately, the same cannot yet be said for INPs.

Although a common, definitive driver of INP climatology was not identified in our study, we will point out a few key findings specific to the respective measurement sites. 


\subsubsection{AZ}

The Amazonian site is characterized by a distinct seasonality of pollutants that follow the biomass burning season. During the dry season (August to November) the aerosol concentration and other pollution markers rise by about 1 order of magnitude compared to the cleaner wet season (February to May) - a change which is largely attributable to human activities. Notably, an effect of the strong anthropogenic biomass burning is absent in the INP signal. In fact, the number of INPs normalized by the total number of aerosol particles (TSI OPS 3330) in a volume of air (i.e., the activated fraction, $\mathrm{AF}$ ) is anti-correlated to parameters related to the abundance of biomass burning products (Fig. 8). The AF can be understood as a simple metric that indicates the ice-nucleating efficiency of particles within a specific aerosol sample. The observed anti-correlation seems to suggest that aerosol particles from fires are relatively poor ice nuclei, an observation that agrees with previously published findings (Kanji et al., 2017, 2020). Considering the recent literature consensus regarding biomass burning INPs, these results are not unexpected. Biomass burning INPs have been studied in the laboratory investigating both surrogate and real combustion particles (Petters et al., 2009; Levin et al., 2016; Kanji et al., 2020) and in the field (Prenni et al., 2012; McCluskey et al., 2014; Schill et al., 2020). Although at least a regional impact of biomass burning on INP abundance is reported, the nucleation temperatures are usually close to the homogeneous freezing limit. Some of these studies suggest that water supersaturation is a requirement for biomass burning aerosol to act as INPs (e.g., Petters et al., 2009; Schill et al., 2020). In this regard, our data may demonstrate the limits of what is explorable with FRIDGE. Either biomass burning aerosol is in fact a poor source for Amazonian INPs in the investigated temperature regime or the method simply cannot represent the freezing behavior of these particles accurately.

Furthermore, the significance of low AFs resulting from biomass burning in this study is difficult to assess, as the seasonality of the AF is largely dominated by the seasonal changes in aerosol concentration for the AZ site. Vegetation fires therefore seem to emit disproportionally more (non-iceactive) aerosol particles than INPs. Another way to interpret the anti-correlation of $\mathrm{AF}$ and biomass burning markers is by coupling the metric to precipitation rates. There are several intricate interactions of note here. On one hand more precipitation leads to higher aerosol particle (and INP) removal by wet deposition. Moreover, enhanced precipitation during the wet season can largely prevent wild fires and the accompanied particle emissions in the first place. On the other hand, it has been postulated previously that precipitation may be a driver of biological INPs (Huffman et al., 2013), and large tropical rainforests like the Amazon have been highlighted in that regard (Morris et al., 2014). However, the processes responsible for the release of the biological particles have not yet been deciphered in detail.

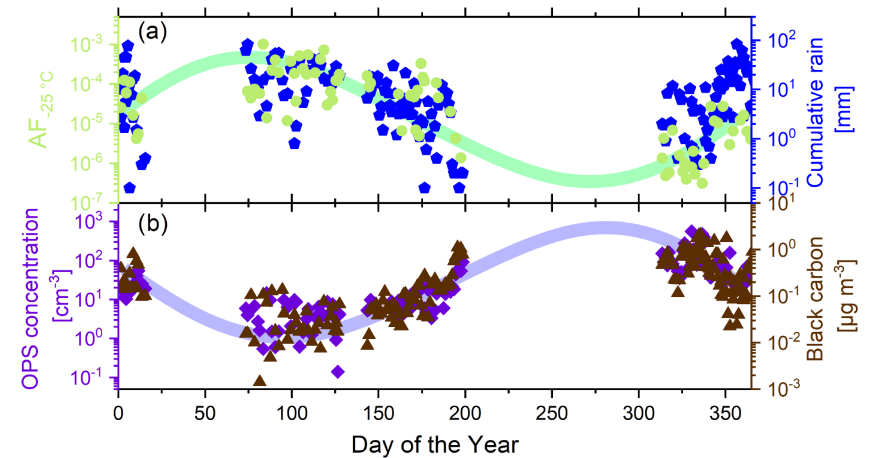

Figure 8. Seasonal variation of the activated fraction at $T=-25^{\circ} \mathrm{C}$ and $\mathrm{RH}_{\text {water }}=101 \%$ at $\mathrm{AZ}$ and the cumulative precipitation along the trajectory reaching the site at the time of sampling (both a). Aerosol number concentration retrieved from a colocated OPS and the black carbon mass concentration (both $\mathbf{b}$ ) at AZ. Lines are added to guide the eye.

Moreover, although the $\mathrm{AZ}$ measurements are somewhat more sparse than those of other stations, our observations do not support significant differences in absolute INP concentrations between dry and wet seasons.

Overall, the INP concentrations of our study compare reasonably well to the measurements of Prenni et al. (2009), who observed average INP concentrations of about $1 \mathrm{~L}^{-1}$ at $-20^{\circ} \mathrm{C}, 4 \mathrm{~L}^{-1}$ at $-25^{\circ} \mathrm{C}$ and $10 \mathrm{~L}^{-1}$ at $-30{ }^{\circ} \mathrm{C}$ using a continuous-flow diffusion chamber (CFDC) to study condensation and immersion mode ice nucleation during a field campaign in February-March 2008 in a region close to the present location of the ATTO site. However, our observed concentrations are clustered at the low end of those presented by Prenni et al. (2009) (i.e., a factor of 5 lower on average at $-30^{\circ} \mathrm{C}$ ), which is presumably due to the different nucleation modes addressed. During that short campaign Prenni et al. (2009) identified mineral dust and carbonaceous aerosol (mostly biological particles) to be the main contributors to atmospheric INPs in the Amazon using transmission electron microscopy and energy-dispersive X-ray spectroscopy.

Within our sampling period, Moran-Zuloaga et al. (2018) identified several long-range transport (LRT) events at the site with markedly increased concentrations of mineral dust during the wet season of 2015/16 (December-January). INP concentrations of these LRT samples were positively correlated with the aerosol number concentration measured with an optical particle counter (TSI OPS 3330; $R=0.80, N=9$, $p<0.01)$. However, mineral dust may be a relevant INP in this region even in the absence of distinct LRT events: an analysis of the average composition of INPs of six samples (four in April 2016 and two in December 2016) using scanning electron microscopy (SEM, Fig. 9), identified that nearly half of the particles that activated to ice crystals in FRIDGE were mineral dust. This finding suggests that there seems to be a well-mixed and diluted background concentra- 

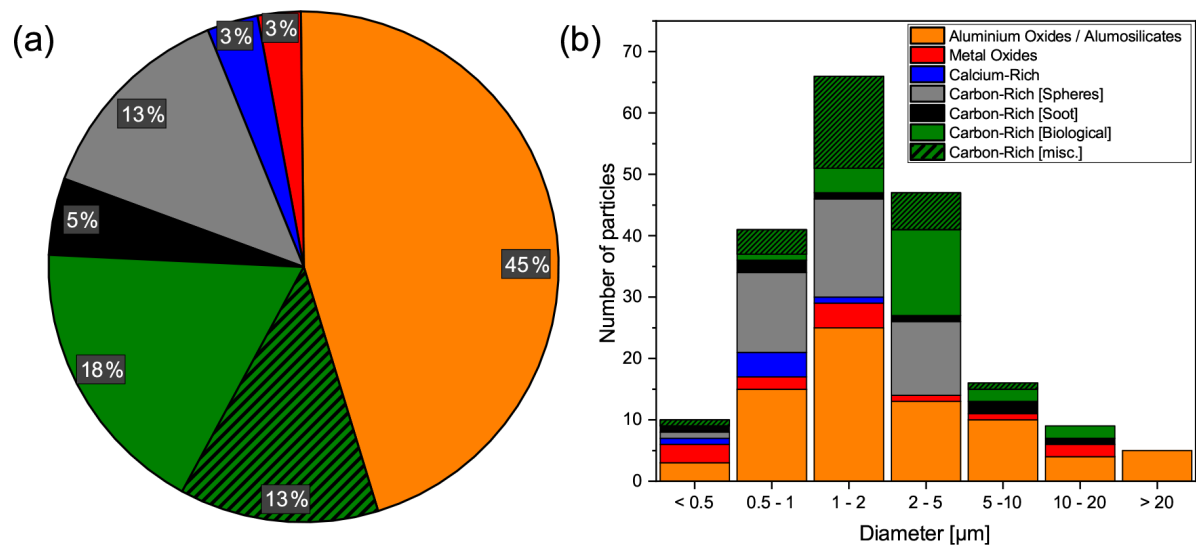

Figure 9. (a) Average INP composition of six equally weighted AZ samples measured by electron microscopy $(N=196)$. (b) Size distribution of identified INPs. Particles labeled as "Carbon-Rich [Spheres]" show distinct features of tar balls and are likely products from biomass burning.

tion of mineral dust INPs at all times present at AZ. The diameter of most of the INPs investigated by SEM in this study was between a single and a couple of micrometers (Fig. 9b). Note, however, that the contribution to the larger size bins might be potentially underrepresented due to particle losses from the inlet configuration. The second half of identified INPs had a strong carbonaceous fraction and consisted of biological particles and biomass burning products. Furthermore, it is possible that some PBAP activity was missed due to the chosen sampling strategy, given local noon is a daily minimum for PBAPs. Qualitatively, these findings agree very well with those of Prenni et al. (2009).

\subsubsection{MQ}

Of the results presented here, the average INP concentration of the Caribbean site was the highest but only by a small margin. There is some evidence that summertime INP concentrations are higher on average than those during winter, although there is no clear seasonality. However, the possible seasonal ice nucleation effects are difficult to assess due to the large interruption of measurements between December 2015 to May 2016. Although we consider it rather speculative, a trend of higher concentrations during summer does stand to reason, as it would reflect the annual cycle of the mineral dust transport, which is driven by the movement of the ITCZ. The seasonality of mineral dust is well reflected by the $\mathrm{PM}_{10}$ concentration, which is monitored routinely in Martinique by the local agency for air quality (MadininAir, 2020). The seasonality of dust motivates a deeper investigation with respect to INPs. In general, we observe a significant correlation between the INP concentration at OVSM and the $\mathrm{PM}_{10}$ concentration at an air quality station close to the observatory (Schoelcher, $14 \mathrm{~km}$ distance), as well as between INPs and the OPS aerosol number concentration at the observatory. The correlations improve for colder temperatures and higher ice supersaturations. At $-30{ }^{\circ} \mathrm{C}$ and $135 \% \mathrm{RH}_{\text {ice }}$ the Pearson correlation coefficients between INP and aerosols are $R=0.46(N=124, p \ll 0.01)$ for $\mathrm{PM}_{10}$ (Fig. S7) and $R=0.50(N=69, p \ll 0.01)$ for the OPS concentration, respectively. We conclude that the MQ INP concentration at the investigated temperatures is likely dominated by natural processes such as the long-range transport of Saharan mineral dust. However, there is still a large variability in the INP signal, which cannot be fully explained by considering only the seasonal dust transport.

We observe significantly lower INP concentrations for all conditions after the large interruption in measurements. For example, the average INP concentration at $-30^{\circ} \mathrm{C}$ and $135 \% \mathrm{RH}_{\text {ice }}$ in 2015 was $7.47 \pm 6.42 \mathrm{~L}^{-1}(N=58)$ and only $1.37 \pm 1.39 \mathrm{~L}^{-1}(N=72)$ in 2016 . This observation does, however, correspond to measured $\mathrm{PM}_{10}$ concentrations, which also show a significantly lower average in 2016 $\left(25 \mu \mathrm{g} \mathrm{m}^{-3}, N=8225\right)$ than $2015\left(35 \mu \mathrm{g} \mathrm{m}^{-3}, N=8636\right)$. Although the observed decrease from 2015 to 2016 of factor of 5 in INP concentrations is large compared to the $\approx 30 \%$ difference in $\mathrm{PM}_{10}$, the cubic scaling implicit in the number to mass translation needs to be considered.

DeMott et al. (2016) presented results from offline immersion freezing experiments and characterized INP concentrations from research flights from St. Croix in the US Virgin Islands and ground sampling from Puerto Rico, which were collected during the ICE-T (the Ice in Clouds Experiment - Tropical) campaign in July 2011. The focus was on marine INPs and determining representative marine background concentrations, and only samples collected within the marine boundary layer were presented. They measured INP concentrations of $0.06 \mathrm{~L}^{-1}$ at $-20^{\circ} \mathrm{C}$ and $0.3 \mathrm{~L}^{-1}$ at $-24^{\circ} \mathrm{C}$, which agrees within a factor of 2 to our median INP concentrations at -20 and $-25^{\circ} \mathrm{C}$. 


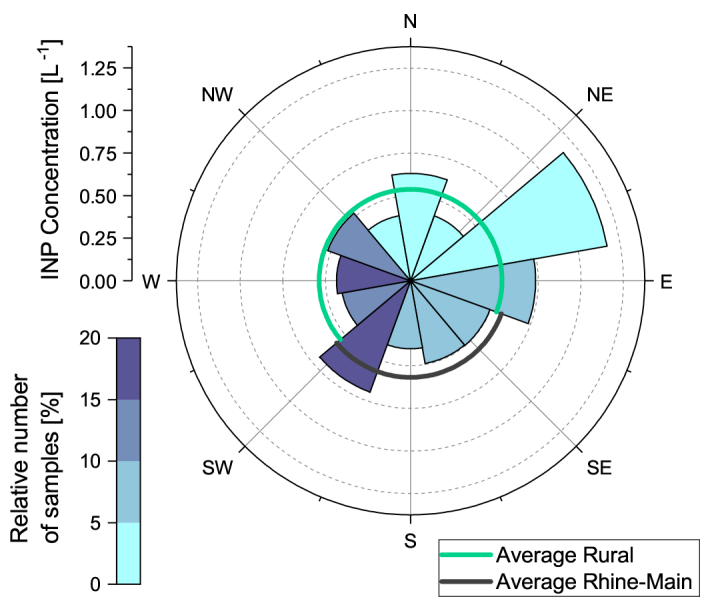

Figure 10. Average INP concentration at $T=-25^{\circ} \mathrm{C}$ and $\mathrm{RH}_{\text {water }}=101 \%$ at TO depending on local wind direction. Note that the wind rose is divided into sectors to match the distinction between the sectors of the metropolitan (black-line average) and rural (green-line average) area according to Table 3 . The relative frequency of local wind directions during sampling is indicated by the color-coding.

\subsubsection{TO}

During the timeframe of the global sampling effort (about 640 d) 400 PEAC7 samples were collected and analyzed from TO (i.e., one sample every $1.6 \mathrm{~d}$ ). The sampling frequency of valid INP concentrations (i.e., above the detection limit) remains as good as one sample every $2 \mathrm{~d}$ for measurements at -20 and $-25^{\circ} \mathrm{C}$. This is by far the best data coverage of the four stations.

We found a moderate but significant correlation between the $\mathrm{PM}_{10}$ concentrations and INPs throughout the spectrum of $T$ and RH conditions. The Pearson correlation coefficient is as high as $R=0.27(N=304, p \ll 0.01)$ at $-25^{\circ} \mathrm{C}$, where we have the best data coverage. Although the particulate matter was significantly enhanced, when wind was coming from the heavily populated and industrialized RhineMain metropolitan region (Table 3), the average INP concentration was not found to differ significantly from other times, when air masses were arriving from other directions (Fig. 10). Therefore, a strong anthropogenic impact on INPs at TO is unlikely.

\subsubsection{SB}

Due to its remoteness and relatively clean atmosphere, the Arctic may be particularly sensitive to small changes in aerosol particulate. Furthermore, within the Arctic climate system there are well-known feedbacks that can amplify small changes in significant ways (Serreze and Francis, 2006; Boy et al., 2019). Historically, this has motivated quite a few research studies targeting ice nucleation in the Arctic environment. For example, clay was identified in the center of
Greenlandic snow crystals by Kumai and Francis (1962) as early as 1960. Past studies generally agree that INP concentrations in the Arctic tend to be on the lower side of the spectrum. Yet, individual findings and conclusions vary considerably (e.g., see Table 2 in Thomson et al., 2018). New ice core records may illuminate long-term trends of Arctic INPs by estimating historic (pre-industrial) concentrations from droplet-freezing experiments of ice core meltwater (Hartmann et al., 2019; Schrod et al., 2020a).

In two recent studies immersion mode ice nucleation in the Arctic was investigated by Tobo et al. (2019) and Wex et al. (2019). Tobo et al. (2019) focused on two field campaigns held in Ny-Ålesund (Zeppelin) in July 2016 (six samples) and March 2017 (seven samples). Wex et al. (2019) report INP concentrations from four pan-Arctic locations (Canada, Alaska, Ny-Ålesund and Greenland) that cover observations ranging from 10 weeks to a full year of mostly weekly sampling. Both studies observed enhanced INP concentrations during summer months. Tobo et al. (2019) report INP concentrations at $-20^{\circ} \mathrm{C}$ of about $0.01 \mathrm{~L}^{-1}$ in March 2017 and about $0.1 \mathrm{~L}^{-1}$ in July 2016 . At $-25^{\circ} \mathrm{C}$ INP concentrations were on the order of 0.1 and $0.5 \mathrm{~L}^{-1}$ for the March and July field campaigns, respectively. Wex et al. (2019) distinguished between samples that were collected in Ny-Ålesund from March to May 2012 (five samples) and those from June to September 2012 (seven samples). During spring, INP concentrations at $-20^{\circ} \mathrm{C}$ were consistently found to be about $0.01 \mathrm{~L}^{-1}$. Most summertime samples were completely frozen before reaching $-20^{\circ} \mathrm{C}$ and thus seem to suggest that concentrations were up to 1 order of magnitude higher in summer. Very recent measurements from Greenland during March-April 2018 qualitatively agree very well with these concentration levels (Hartmann et al., 2020). However, a recent study by Rinaldi et al. (2020) did not observe a distinct seasonal signal in their INP measurements between -15 and $-22^{\circ} \mathrm{C}$ in the spring and summer of 2018 in NyÅlesund. Rinaldi et al. (2020) present INP concentrations from two separate methods, one of which is fairly similar to FRIDGE, addressing the condensation freezing (DFPC; Dynamic Filter Processing Chamber) and immersion freezing (West Texas Cryogenic Refrigerator Applied to Freezing Test; WT-CRAFT) modes.

Further, Wex et al. (2019) report correlation coefficients with complementary measurements that are mostly insignificant including $\mathrm{PM}_{10}$. Exceptions include significant correlations between INPs and sulfate $(R=-0.6)$ and potassium $(R=-0.57)$, pointing to complex factors determining the Arctic INP population. Moreover, Tobo et al. (2019) present evidence that mineral dust (possibly with organic inclusions) from Arctic glacial outwash plains influence the INP activity in Ny-Ålesund. They conclude that these glacial sediments may be a large-scale source of mineral dust in the Arctic. Rinaldi et al. (2020) present evidence that Arctic INP concentrations are influenced by sources of marine biological INPs by providing a spatiotemporal correlation analysis be- 
tween chlorophyll $a$ fields from satellite data and a trajectory model.

We present a significantly larger data set with respect to temporal coverage, and our INP concentrations agree well with these previous studies from $\mathrm{Ny}$ - $\AA$ lesund. At $-20{ }^{\circ} \mathrm{C}$ we find concentrations of about $0.1 \mathrm{~L}^{-1}$. At $-25^{\circ} \mathrm{C}$ the average INP concentration increases to about $0.3 \mathrm{~L}^{-1}$. However, the frequently reported finding of summertime INP enhancement does not emerge from our analysis. Furthermore, we did not observe any seasonal changes in the INP signal with regards to the anthropogenic Arctic haze phenomenon. Moreover, we did not observe significant correlations between INPs and available aerosol parameters. The concerning lack of meaningful correlations and/or seasonal trends may be in part related to a relatively poor signal-to-noise ratio in our SB measurements. INP concentrations were often at or close to the limit of detection or the significance level, respectively. In retrospect, we now would increase the sampling volume for $\mathrm{SB}$ measurements to be able to resolve lower concentrations more accurately.

\section{Conclusions}

The data from our small but unique measurement network can be considered particularly valuable, and we hope lessons can be learned from this effort that will help to guide future INP monitoring efforts. Significant infrastructural and logistical investments are represented by the INP measurements that cover an observational period of 21 months in total. Well above 1000 samples were collected, retrieved and analyzed in this project at a large array of temperature and supersaturation conditions, characterizing the INP concentrations in the deposition and condensation freezing modes. The investigated sites represent diverse climatic regions and ecosystems that experience varying degrees of anthropogenic influence.

In spite of the great differences in basically all characteristics that are expected to define the aerosol concentration, composition and source apportionment, we observed fairly similar INP concentrations for all four stations for the methods and sampling strategy applied. In our study, average concentrations differed between sites by less than a factor of 5 . Short-term variability dominated most of the total variability at all locations. Trends, annual cycles and well-defined peak concentrations were prominently absent from the time series. Still, the range of observed INP concentrations do compare reasonably well with previously published literature, where available. Importantly, the relative frequencies of observed INP concentrations are generally well represented by lognormal distributions, a finding that suggests distributed INP sources that result from INPs being well mixed within sampled air masses. These findings emphasize the important contribution of INPs from background air masses. Moreover, no physical or chemical parameter was identified to continu- ously covary with INPs at all sites, and therefore a comprehensive causal link to INP concentrations remains lacking.

Overall, we did not detect much evidence for a strong anthropogenic impact on the concentrations of ice-nucleating particles. At AZ the INP concentrations appear unrelated to human-induced biomass burning, which otherwise leads to a 10-fold increase in aerosol particle number concentrations during the dry season. The INP concentrations at MQ were well correlated with aerosol characteristics that are driven by natural processes, like long-range transport of Saharan mineral dust and marine aerosol production. Average TO INP concentrations showed no significant difference between wind sectors that can be separated into anthropogenically dominated areas and rural environments. Likewise, no significant changes in the INP concentration were observed at SB during the Arctic haze period.

Considering these findings, the approach of estimating order-of-magnitude pre-industrial INP concentrations from present-day measurements in near-pristine locations does seem to both be viable and yields reasonable results, which merit further investigation. In this sense, we consider the lower-concentration end of our measurements likely to be the most realistic assessment of pre-industrial atmospheric INP concentrations. However, when using the presented data one should be aware of the substantial limitations of the conceptual aspect of the approach and the uncertainties that are inherent in the aerosol sampling and INP measurements themselves.

\section{Outlook}

This study clearly highlights that there is a strong need for increased continuous observations of INPs worldwide. Several important questions need to be addressed by the community when considering how to best implement a systematic longterm monitoring strategy:

(1) What are the best time resolution(s) and sampling frequencies? Obviously, the answer to this depends on the scientific question that a group is trying to address and the requirements and capabilities of the specific INP counter. Furthermore, bearing in mind that INP measurements are primarily of interest for illuminating cloud and precipitation processes it may be important to recognize that cloud processes are geographically different, and thus the answers to these questions may also differ. For example, for areas where tropical and subtropical deep convection dominates cloud formation, sampling priorities may differ from the midlatitudes where synoptic-scale weather systems are predominant. Judging from the results we have presented, it could be argued that longer sampling times (several hours to days) are advantageous for elucidating longer-term trends. Longer sampling may effectively act as a low-pass filter and thereby reduce the considerable short-term variability in INPs that is observed everywhere. Naturally, ideal monitoring could be done with 
short but densely spaced sampling times. This would enable averaging to be done at the data analysis level, and thus both short- and long-term variation could be reasonably captured. However, such an instrument and/or technique has not been available in the past and will likely present both technological and human resource challenges. In the meantime, we suggest that long-term measurements are initiated with some weeks of intensive measurements to establish baseline information with regard to INP concentration and variability.

(2) What supporting instrumentation or measurements should accompany the INP monitoring? Naturally, it is good to have as much information about aerosol concentration, size distribution and chemical composition as possible. However, a thorough aerosol characterization does not guarantee robust correlations with INPs or even a fully explained total INP variability. To date the community has had limited success in using colocated measurements to establish causal links with INPs. Initiating further long-term measurements at highly equipped research stations may be a pathway towards learning what additional tools best complement INP studies.

(3) What measurement conditions and nucleation modes should be addressed? Again, this depends on the both the researchers scientific focus and the capabilities of the respective INP instrument. However, the literature consensus firmly suggests that immersion freezing is the most atmospherically relevant nucleation mechanism.

From the experience built in this study, we recommend that those undertaking future studies, especially those that include remote sampling locations, plan conservatively for the required logistics and workload, with respect to sampling frequency, analysis conditions, sampling consistency, etc. We emphasize the importance of a well-conceived sampling strategy and well-laid-out logistics. Instrument malfunctions, maintenance and various other difficulties and interruptions are to be expected. All of these may be easily addressed separately but amount to a significant challenge when a longdistance network is to be kept running across a hemisphere. Nonetheless, we encourage other groups and collaborations to more strongly emphasize long-time observations in addition to the common standard of campaign-based measurements. Although we are currently far from the best-case scenario of a (near-)continuous automated global network of INP measurements, there are promising new developments (e.g., Bi et al., 2019; Brunner and Kanji, 2020; Möhler et al., 2020 ) that may provide a vital step towards long-term (semi)automated measurements of immersion mode INPs in the near future.

In addition to the goal of establishing more long-term global observations of continuous INP concentrations there are certainly other important areas for future research to address. For example, as most measurements are conducted at ground level, we believe there is a need to systematically study the vertical distribution of INPs - for example at heights where INPs are transported over long ranges and/or where cloud formation occurs. Moreover, more ex- tensive data sets from long-term INP monitoring might shed light on what mechanisms result in the observed log-normal INP frequency distributions (departures from ideality, etc.) as presented here and, for example, by Welti et al. (2018). Murray et al. (2020) have recently enumerated many crucial areas into which future INP research should delve. First and foremost, the authors emphasize the need to accurately implement ice-nucleation-related cloud-phase interactions in climate models in order to predict future climate scenarios correctly. We gladly refer the interested reader to Murray et al. (2020) for a more extensive list of future ice-nucleationrelated research questions than is presented in this study.

Data availability. The INP data of this study have been uploaded to the PANGAEA data repository: https://doi.org/10.1594/ PANGAEA.925732 (last access: 18 December 2020, Schrod et al., 2020b).

Supplement. The supplement related to this article is available online at: https://doi.org/10.5194/acp-20-15983-2020-supplement.

Author contributions. JaS, JK and DW performed the INP measurements. JaS compiled and analyzed the INP data with the support of JK and HGB. JaS created the figures. Particle measurements at ATTO were performed by CP, JoS and FD. ME performed the SEM measurements. All authors took part in the discussion of the results. $\mathrm{JaS}$ wrote the paper together with HGB and EST, receiving valuable input from the other coauthors.

Competing interests. The authors declare that they have no conflict of interest.

Disclaimer. This paper contains results of research conducted under the technical-scientific cooperation agreement between the National Institute of Amazonian Research, the Amazonas State University and the Max-Planck-Gesellschaft e.V.; the opinions expressed are the entire responsibility of the authors and not of the participating institutions.

Special issue statement. This article is part of the special issues "BACCHUS - Impact of Biogenic versus Anthropogenic emissions on Clouds and Climate: towards a Holistic UnderStanding (ACP/AMT/GMD inter-journal SI)" and "Amazon Tall Tower Observatory (ATTO) Special Issue". It is not associated with a conference.

Acknowledgements. The work was initiated and primarily carried out within the context of the EU FP7-ENV-2013 BACCHUS project under grant agreement 603445 . The experimental methods and instruments were established through financial support of Deutsche 
Forschungsgemeinschaft under research cooperations SFB 641 and FOR 1525 (INUIT). We thank the technical and scientific personnel of the stations ATTO and Zeppelin Observatory (Norwegian Polar Institute) and of the Volcanological Observatory of Martinique (Frédéric Jadélus and David Mélézan) for their valuable help on site during the campaigns. We thank AWI and AWIPEV staff, including Verena Mohaupt, for the logistics provided in sample transport to and from Ny-Ålesund. We thank Hans-Christen Hansson for his valuable scientific input and the supporting aerosol data from Ny-Ålesund. We thank HLNUG and MadininAir for providing air quality data for TO and MQ, respectively. For the operation of the ATTO site, we acknowledge the support by the German Federal Ministry of Education and Research (BMBF contract nos. 01LB1001A and 01LK1602B) and the Brazilian Ministério da Ciência, Tecnologia e Inovação (MCTI/FINEP contract no. 01.11.01248.00) as well as the Amazonas State University (UEA), FAPEAM, LBA/INPA and SDS/CEUC/RDS-Uatumã. We further thank Susan Trumbore, Carlos Alberto Quesada, Reiner Ditz, Stefan Wolff, Jürgen Kesselmeier, Andrew Crozier, Antonio Huxley Melo Nascimento, Wallace Rabelo Costa, Daniel MoranZuloaga, Isabella Hrabe de Angelis, Maria Praß, Björn Nillius, Meinrat O. Andreae and Ulrich Pöschl for their support and inspiring discussions. Paulo Artaxo acknowledges funding from FAPESP - Fundação de Amparo à Pesquisa do Estado de São Paulo through grant 2017-17047-0. Erik S. Thomson's contribution has also been supported by the Swedish Research Council, VR (2013-05153) and FORMAS (2017-00564) and the Swedish Strategic Research Area MERGE.

Financial support. This research has been supported by the Seventh Framework Programme (BACCHUS (grant no. 603445)).

This open-access publication was funded by the Goethe University Frankfurt.

Review statement. This paper was edited by Hinrich Grothe and reviewed by Paul DeMott and one anonymous referee.

\section{References}

Andreae, M. O.: Aerosols Before Pollution, Science, 315, 50-51, https://doi.org/10.1126/science.1136529, 2007.

Andreae, M. O., Jones, C. D., and Cox, P. M.: Strong present-day aerosol cooling implies a hot future, Nature, 435, 1187-1190, https://doi.org/10.1038/nature03671, 2005.

Andreae, M. O., Acevedo, O. C., Araùjo, A., Artaxo, P., Barbosa, C. G. G., Barbosa, H. M. J., Brito, J., Carbone, S., Chi, X., Cintra, B. B. L., da Silva, N. F., Dias, N. L., Dias-Júnior, C. Q., Ditas, F., Ditz, R., Godoi, A. F. L., Godoi, R. H. M., Heimann, M., Hoffmann, T., Kesselmeier, J., Könemann, T., Krüger, M. L., Lavric, J. V., Manzi, A. O., Lopes, A. P., Martins, D. L., Mikhailov, E. F., Moran-Zuloaga, D., Nelson, B. W., Nölscher, A. C., Santos Nogueira, D., Piedade, M. T. F., Pöhlker, C., Pöschl, U., Quesada, C. A., Rizzo, L. V., Ro, C.-U., Ruckteschler, N., Sá, L. D. A., de Oliveira Sá, M., Sales, C. B., dos Santos, R. M. N., Saturno, J., Schöngart, J., Sörgel, M., de Souza, C. M., de Souza,
R. A. F., Su, H., Targhetta, N., Tóta, J., Trebs, I., Trumbore, S., van Eijck, A., Walter, D., Wang, Z., Weber, B., Williams, J., Winderlich, J., Wittmann, F., Wolff, S., and Yáñez-Serrano, A. M.: The Amazon Tall Tower Observatory (ATTO): overview of pilot measurements on ecosystem ecology, meteorology, trace gases, and aerosols, Atmos. Chem. Phys., 15, 10723-10776, https://doi.org/10.5194/acp-15-10723-2015, 2015.

Atkinson, J. D., Murray, B. J., Woodhouse, M. T., Whale, T. F., Baustian, K. J., Carslaw, K. S., Dobbie, S., O'Sullivan, D., and Malkin, T. L.: The importance of feldspar for ice nucleation by mineral dust in mixed-phase clouds, Nature, 498, 355-358, https://doi.org/10.1038/nature12278, 2013.

Bi, K., McMeeking, G. R., Ding, D., Levin, E. J. T., DeMott, P. J., Zhao, D., Wang, F., Liu, Q., Tian, P., Ma, X., Chen, Y., Huang, M., Zhang, H., Gordon, T., and Chen, P.: Measurements of ice nucleating particles in Beijing, China, J. Geophys. Res.-Atmos., 124, 8065-8075, https://doi.org/10.1029/2019JD030609, 2019.

Bigg, E. K.: Ice nucleus concentrations in remote areas, J. Atmos. Sci., 30, 1153-1157, https://doi.org/10.1175/15200469(1973)030<1153:INCIRA>2.0.CO;2, 1973.

Bigg, E. K. and Miles, G. T.: The results of largescale measurements of natural ice nuclei, J. Atmos. Sci., 21, 396-403, https://doi.org/10.1175/15200469(1964)021<0396:TROLMO>2.0.CO;2, 1964.

Boucher, O., Randall, D., Artaxo, P., Bretherton, C., Feingold, P. G., Forster, F. G., Kerminen, V.-M., Kondo, Y., Liao, H., Lohmann, U., Rasch, P., Satheesh, S. K., Sherwood, S., Stevens, B., and Zhang, X. Y.: Clouds and Aerosols. Version: 2013, Chapt. 7, in: Climate Change 2013: The Physical Science Basis. Contribution of Working Group I to the Fifth Assessment Report of the Intergovernmental Panel on Climate Change, edited by: Stocker, T. F., Qin, D., Plattner, G.-K., Tignor, M., Allen, S. K., Boschung, J., Nauels, A., Xia, Y., Bex, V., and Midgley, P. M., Cambridge University Press, Cambridge, United Kingdom and New York, NY, USA, https://doi.org/10.1017/CBO9781107415324.016, 571658, 2013.

Boy, M., Thomson, E. S., Acosta Navarro, J.-C., Arnalds, O., Batchvarova, E., Bäck, J., Berninger, F., Bilde, M., Brasseur, Z., Dagsson-Waldhauserova, P., Castarède, D., Dalirian, M., de Leeuw, G., Dragosics, M., Duplissy, E.-M., Duplissy, J., Ekman, A. M. L., Fang, K., Gallet, J.-C., Glasius, M., Gryning, S.-E., Grythe, H., Hansson, H.-C., Hansson, M., Isaksson, E., Iversen, T., Jonsdottir, I., Kasurinen, V., Kirkevåg, A., Korhola, A., Krejci, R., Kristjansson, J. E., Lappalainen, H. K., Lauri, A., Leppäranta, M., Lihavainen, H., Makkonen, R., Massling, A., Meinander, O., Nilsson, E. D., Olafsson, H., Pettersson, J. B. C., Prisle, N. L., Riipinen, I., Roldin, P., Ruppel, M., Salter, M., Sand, M., Seland, Ø., Seppä, H., Skov, H., Soares, J., Stohl, A., Ström, J., Svensson, J., Swietlicki, E., Tabakova, K., Thorsteinsson, T., Virkkula, A., Weyhenmeyer, G. A., Wu, Y., Zieger, P., and Kulmala, M.: Interactions between the atmosphere, cryosphere, and ecosystems at northern high latitudes, Atmos. Chem. Phys., 19, 2015-2061, https://doi.org/10.5194/acp-192015-2019, 2019.

Bundke, U., Nillius, B., Jaenicke, R., Wetter, T., Klein, H., and Bingemer, H.: The fast Ice Nu- 
cleus chamber FINCH, Atmos. Res., 90, 180-186, https://doi.org/10.1016/j.atmosres.2008.02.008, 2008.

Brunner, C. and Kanji, Z. A.: Continuous online-monitoring of Ice Nucleating Particles: development of the automated Horizontal Ice Nucleation Chamber (HINC-Auto), Atmos. Meas. Tech. Discuss., https://doi.org/10.5194/amt-2020-306, in review, 2020.

Carslaw, K. S., Lee, L. A., Reddington, C. L., Pringle, K. J., Rap, A., Forster, P. M., Mann, G. W., Spracklen, D. V., Woodhouse, M. T., Regayre, L. A., and Pierce, J. R.: Large contribution of natural aerosols to uncertainty in indirect forcing, Nature, 503, 67-71, https://doi.org/10.1038/nature12674, 2013.

Carslaw, K. S., Gordon, H., Hamilton, D. S., Johnson, J. S., Regayre, L. A., Yoshioka, M., and Pringle, K. J.: Aerosols in the Pre-industrial Atmosphere, Curr. Clim. Change Rep., 3, 1-15, https://doi.org/10.1007/s40641-017-0061-2, 2017.

Chen, J., Wu, Z., Augustin-Bauditz, S., Grawe, S., Hartmann, M., Pei, X., Liu, Z., Ji, D., and Wex, H.: Icenucleating particle concentrations unaffected by urban air pollution in Beijing, China, Atmos. Chem. Phys., 18, 3523-3539, https://doi.org/10.5194/acp-18-3523-2018, 2018.

David, R. O., Fahrni, J., Marcolli, C., Mahrt, F., Brühwiler, D., and Kanji, Z. A.: The role of contact angle and pore width on pore condensation and freezing, Atmos. Chem. Phys., 20, 9419-9440, https://doi.org/10.5194/acp-20-9419-2020, 2020.

Davidson, E. A., de Araujo, A. C., Artaxo, P., Balch, J. K., Brown, I. F., C.,Bustamante, M. M., Coe, M. T., DeFries, R. S., Keller, M., Longo, M., Munger, J. W., Schroeder, W., Soares-Filho, B. S., Souza, C. M., and Wofsy, S. C.: The Amazon basin in transition, Nature, 481, 7381, 321-328, https://doi.org/10.1038/nature10717, 2012.

DeMott, P. J., Prenni, A. J., Liu, X., Kreidenweis, S. M., Petters, M. D., Twohy, C. H., Richardson, M. S., Eidhammer T., and Rogers, D. C.: Predicting global atmospheric ice nuclei distributions and their impacts on climate, P. Natl. Acad. Sci. USA, 107, 11217-11222, https://doi.org/10.1073/pnas.0910818107, 2010.

DeMott, P. J., Möhler, O., Stetzer, O., Vali, G., Levin, Z., Petters, M. D., Murakami, M., Leisner, T., Bundke, U., Klein, H., Kanji, Z. A., Cotton, R., Jones, H., Benz, S., Brinkmann, M., Rzesanke, D., Saathoff, H., Nicolet, M., Saito, A., Nillius, B., Bingemer, H., Abbatt, J., Ardon, K., Ganor, E., Georgakopoulos, D. G., and Saunders, C.: Resurgence in Ice Nuclei Measurement Research, B. Am. Meteorol. Soc., 92, 1623-1635, https://doi.org/10.1175/2011BAMS3119.1, 2011.

DeMott, P. J., Prenni, A. J., McMeeking, G. R., Sullivan, R. C., Petters, M. D., Tobo, Y., Niemand, M., Möhler, O., Snider, J. R., Wang, Z., and Kreidenweis, S. M.: Integrating laboratory and field data to quantify the immersion freezing ice nucleation activity of mineral dust particles, Atmos. Chem. Phys., 15, 393-409, https://doi.org/10.5194/acp-15-393-2015, 2015.

DeMott, P. J., Hill, T. C. J., McCluskey, C. S., Prather, K. A., Collins, D. B., Sullivan, R. C., Ruppel, M. J., Mason, R. H., Irish, V. E., Lee, T., Hwang, C. Y., Rhee, T. S., Snider, J. R., McMeeking, G. R., Dhaniyala, S., Lewis, E. R., Wentzell, J. J. B., Abbatt, J., Lee, C., Sultana, C. M., Ault, A. P., Axson, J. L., Diaz Martinez, M., Venero, I., Santos-Figueroa, G., Stokes, M. D., Deane, G. B., Mayol-Bracero, O. L., Grassian, V. H., Bertram, T. H., Bertram, A. K., Moffett, B. F., and Franc, G. D.: Sea spray aerosol as a unique source of ice nu- cleating particles, P. Natl. Acad. Sci. USA, 113, 5797-5803, https://doi.org/10.1073/pnas.1514034112, 2016.

DeMott, P. J., Möhler, O., Cziczo, D. J., Hiranuma, N., Petters, M. D., Petters, S. S., Belosi, F., Bingemer, H. G., Brooks, S. D., Budke, C., Burkert-Kohn, M., Collier, K. N., Danielczok, A., Eppers, O., Felgitsch, L., Garimella, S., Grothe, H., Herenz, P., Hill, T. C. J., Höhler, K., Kanji, Z. A., Kiselev, A., Koop, T., Kristensen, T. B., Krüger, K., Kulkarni, G., Levin, E. J. T., Murray, B. J., Nicosia, A., O'Sullivan, D., Peckhaus, A., Polen, M. J., Price, H. C., Reicher, N., Rothenberg, D. A., Rudich, Y., Santachiara, G., Schiebel, T., Schrod, J., Seifried, T. M., Stratmann, F., Sullivan, R. C., Suski, K. J., Szakáll, M., Taylor, H. P., Ullrich, R., Vergara-Temprado, J., Wagner, R., Whale, T. F., Weber, D., Welti, A., Wilson, T. W., Wolf, M. J., and Zenker, J.: The Fifth International Workshop on Ice Nucleation phase 2 (FIN-02): laboratory intercomparison of ice nucleation measurements, Atmos. Meas. Tech., 11, 6231-6257, https://doi.org/10.5194/amt11-6231-2018, 2018.

Eckhardt, S., Hermansen, O., Grythe, H., Fiebig, M., Stebel, K., Cassiani, M., Baecklund, A., and Stohl, A.: The influence of cruise ship emissions on air pollution in Svalbard - a harbinger of a more polluted Arctic?, Atmos. Chem. Phys., 13, 8401-8409, https://doi.org/10.5194/acp-13-8401-2013, 2013.

Eleftheriadis, K. and Vratolis, S., and Nyeki, S.: Aerosol black carbon in the European Arctic: Measurements at Zeppelin station, Ny-Alesund, Svalbard from 1998-2007, Geophys. Res. Lett., 36, L02809, https://doi.org/10.1029/2008GL035741, 2009.

Garimella, S., Kristensen, T. B., Ignatius, K., Welti, A., Voigtländer, J., Kulkarni, G. R., Sagan, F., Kok, G. L., Dorsey, J., Nichman, L., Rothenberg, D. A., Rösch, M., Kirchgäßner, A. C. R., Ladkin, R., Wex, H., Wilson, T. W., Ladino, L. A., Abbatt, J. P. D., Stetzer, O., Lohmann, U., Stratmann, F., and Cziczo, D. J.: The SPectrometer for Ice Nuclei (SPIN): an instrument to investigate ice nucleation, Atmos. Meas. Tech., 9, 2781-2795, https://doi.org/10.5194/amt-9-2781-2016, 2016.

Gordon, H., Sengupta, K. Rap, A., Duplissy, J., Frege, C., Williamson, C., Heinritzi, M., Simon, M., Yan, C., Almeida, J., Tröstl, J., Nieminen, T., Ortega, I. K., Wagner, R., Dunne, E. M., Adamov, A., Amorim, A., Bernhammer, A.-K., Bianchi, F., Breitenlechner, M., Brilke, S., Chen, X., Craven, J. S., Dias, A., Ehrhart, S., Fischer, L., Flagan, R. C., Franchin, A., Fuchs, C., Guida, R., Hakala, J., Hoyle, C. R., Jokinen, T., Junninen, H., Kangasluoma, J., Kim, J., Kirkby, J., Krapf, M., Kürten, A., Laaksonen, A., Lehtipalo, K., Makhmutov, V., Mathot, S., Molteni, U., Monks, S. A., Onnela, A., Peräkylä, O., Piel, F., Petäjä, T., Praplan, A. P., Pringle, K. J., Richards, N. A. D., Rissanen, M. P., Rondo, L., Sarnela, N., Schobesberger, S., Scott, C. E., Seinfeld, J. H., Sharma, S., Sipilä, M., Steiner, G., Stozhkov, Y., Stratmann, F., Tome, A., Virtanen, A., Vogel, A. L., Wagner, A. C., Wagner, P. E., Weingartner, E., Wimmer, D., Winkler, P. M., Ye, P., Zhang, X., Hansel, A., Dommen, J., Donahue, N. M., Worsnop, D. R., Baltensperger, U., Kulmala, M., Curtius, J., and Carslaw, K. S.: Reduced anthropogenic aerosol radiative forcing caused by biogenic new particle formation, P. Natl. Acad. Sci. USA, 113, 12053-12058, https://doi.org/10.1073/pnas.1602360113, 2016.

Gordon, H., Kirkby, J., Baltensperger, U., Bianchi, F., Breitenlechner, M., Curtius, J., Dias, A., Dommen, J., Donahue, N. M., Dunne, E. M., Duplissy, J., Ehrhart, S., Fla- 
gan, R. C., Frege, C., Fuchs, C., Hansel, A., Hoyle, C. R., Kulmala, M., Kürten, A., Lehtipalo, K., Makhmutov, V., Molteni, U., Rissanen, M. P., Stozkhov, Y., Tröstl, J., Tsagkogeorgas, G., Wagner, R., Williamson, C., Wimmer, D., Winkler, P. M., Yan, C., and Carslaw, K. S.: Causes and importance of new particle formation in the present-day and preindustrial atmospheres, J. Geophys. Res.-Atmos., 122, 8739-8760, https://doi.org/10.1002/2017JD026844, 2017.

Gute, E., Lacher, L., Kanji, Z. A., Kohl, R., Curtius, J., Weber, D., Bingemer, H., Clemen, H.-C., Schneider, J., GyselBeer, M., Ferguson, S. T., and Abbatt, J. P. D.: Field evaluation of a Portable Fine Particle Concentrator (PFPC) for ice nucleating particle measurements, Aerosol Sci. Tech., 53, 1067-1078, https://doi.org/10.1080/02786826.2019.1626346, 2019.

Hamilton, D. S.: Natural aerosols and climate: Understanding the unpolluted atmosphere to better understand the impacts of pollution, Weather, 70, 264-268, https://doi.org/10.1002/wea.2540, 2015.

Hamilton, D. S., Lee, L. A., Pringle, K. J., Reddington, C. L., Spracklen, D. V., and Carslaw, K. S.: Occurrence of pristine aerosol environments on a polluted planet, P. Natl. Acad. Sci. USA, 111, 18466-18471, https://doi.org/10.1073/pnas.1415440111, 2014.

Hartmann, M., Blunier, T., Brügger, S. O., Schmale, J., Schwikowski, M., Vogel, A., Wex, H., and Stratmann, F.: Variation of ice nucleating particles in the European Arctic over the last centuries, Geophys. Res. Lett., 46, 4007-4016, https://doi.org/10.1029/2019GL082311, 2019.

Hartmann, M., Adachi, K., Eppers, O., Haas, C., Herber, A., Holzinger, R., Hünerbein, A., Jäkel, E., Jentzsch, C., van Pinxteren, M., Wex, H., Willmes, S., and Stratmann, F.: Wintertime airborne measurements of ice nucleating particles in the high Arctic: A hint to a marine, biogenic source for ice nucleating particles, Geophys. Res. Lett., 47, e2020GL087770, https://doi.org/10.1029/2020GL087770, 2020.

Hiranuma, N., Augustin-Bauditz, S., Bingemer, H., Budke, C., Curtius, J., Danielczok, A., Diehl, K., Dreischmeier, K., Ebert, M., Frank, F., Hoffmann, N., Kandler, K., Kiselev, A., Koop, T., Leisner, T., Möhler, O., Nillius, B., Peckhaus, A., Rose, D., Weinbruch, S., Wex, H., Boose, Y., DeMott, P. J., Hader, J. D., Hill, T. C. J., Kanji, Z. A., Kulkarni, G., Levin, E. J. T., McCluskey, C. S., Murakami, M., Murray, B. J., Niedermeier, D., Petters, M. D., O'Sullivan, D., Saito, A., Schill, G. P., Tajiri, T., Tolbert, M. A., Welti, A., Whale, T. F., Wright, T. P., and Yamashita, K.: A comprehensive laboratory study on the immersion freezing behavior of illite NX particles: a comparison of 17 ice nucleation measurement techniques, Atmos. Chem. Phys., 15, 2489-2518, https://doi.org/10.5194/acp-15-2489-2015, 2015.

Hiranuma, N., Adachi, K., Bell, D. M., Belosi, F., Beydoun, H., Bhaduri, B., Bingemer, H., Budke, C., Clemen, H.-C., Conen, F., Cory, K. M., Curtius, J., DeMott, P. J., Eppers, O., Grawe, S., Hartmann, S., Hoffmann, N., Höhler, K., Jantsch, E., Kiselev, A., Koop, T., Kulkarni, G., Mayer, A., Murakami, M., Murray, B. J., Nicosia, A., Petters, M. D., Piazza, M., Polen, M., Reicher, N., Rudich, Y., Saito, A., Santachiara, G., Schiebel, T., Schill, G. P., Schneider, J., Segev, L., Stopelli, E., Sullivan, R. C., Suski, K., Szakáll, M., Tajiri, T., Taylor, H., Tobo, Y., Ullrich, R., Weber, D., Wex, H., Whale, T. F., Whiteside, C. L., Yamashita, K., Zelenyuk, A., and Möhler, O.: A comprehensive characteriza- tion of ice nucleation by three different types of cellulose particles immersed in water, Atmos. Chem. Phys., 19, 4823-4849, https://doi.org/10.5194/acp-19-4823-2019, 2019.

HLNUG: Hessian Agency for Nature Conservation, Environment and Geology: Measurement Site Kleiner Feldberg, available at: https://www.hlnug.de/?id=9231\&station=675, last access: 9 March 2020.

Holanda, B. A., Pöhlker, M. L., Walter, D., Saturno, J., Sörgel, M., Ditas, J., Ditas, F., Schulz, C., Franco, M. A., Wang, Q., Donth, T., Artaxo, P., Barbosa, H. M. J., Borrmann, S., Braga, R., Brito, J., Cheng, Y., Dollner, M., Kaiser, J. W., Klimach, T., Knote, C., Krüger, O. O., Fütterer, D., Lavrič, J. V., Ma, N., Machado, L. A. T., Ming, J., Morais, F. G., Paulsen, H., Sauer, D., Schlager, H., Schneider, J., Su, H., Weinzierl, B., Walser, A., Wendisch, M., Ziereis, H., Zöger, M., Pöschl, U., Andreae, M. O., and Pöhlker, C.: Influx of African biomass burning aerosol during the Amazonian dry season through layered transatlantic transport of black carbon-rich smoke, Atmos. Chem. Phys., 20, 4757-4785, https://doi.org/10.5194/acp-20-4757-2020, 2020.

Huffman, J. A., Sinha, B., Garland, R. M., Snee-Pollmann, A., Gunthe, S. S., Artaxo, P., Martin, S. T., Andreae, M. O., and Pöschl, U.: Size distributions and temporal variations of biological aerosol particles in the Amazon rainforest characterized by microscopy and real-time UV-APS fluorescence techniques during AMAZE-08, Atmos. Chem. Phys., 12, 11997-12019, https://doi.org/10.5194/acp-12-11997-2012, 2012.

Huffman, J. A., Prenni, A. J., DeMott, P. J., Pöhlker, C., Mason, R. H., Robinson, N. H., Fröhlich-Nowoisky, J., Tobo, Y., Després, V. R., Garcia, E., Gochis, D. J., Harris, E., MüllerGermann, I., Ruzene, C., Schmer, B., Sinha, B., Day, D. A., Andreae, M. O., Jimenez, J. L., Gallagher, M., Kreidenweis, S. M., Bertram, A. K., and Pöschl, U.: High concentrations of biological aerosol particles and ice nuclei during and after rain, Atmos. Chem. Phys., 13, 6151-6164, https://doi.org/10.5194/acp13-6151-2013, 2013.

IPCC (IPCC Core Writing Team, Pachauri, R. K., and Meyer, L. A. (Eds.)): Climate Change 2014: Synthesis Report. Contribution of Working Groups I, II and III to the Fifth Assessment Report of the Intergovernmental Panel on Climate Change, IPCC, Geneva, Switzerland, 151 pp., 2014.

Kanji, Z. A., Ladino, L. A., Wex, H., Boose, Y., BurkertKohn, M., Cziczo, D. J., and Krämer, M.: Overview of Ice Nucleating Particles, Meteor. Mon., 58, 1.1-1.33, https://doi.org/10.1175/AMSMONOGRAPHS-D-16-0006.1, 2017.

Kanji, Z. A., Welti, A., Corbin, J. C., and Mensah, A. A.: Black Carbon Particles Do Not Matter for Immersion Mode Ice Nucleation, Geophys. Res. Lett., 47, e2019GL086764, https://doi.org/10.1029/2019GL086764, 2020.

Karlsson, L., Krejci, R., Koike, M., Ebell, K., and Zieger, P.: The role of nanoparticles in Arctic cloud formation, Atmos. Chem. Phys. Discuss., https://doi.org/10.5194/acp-2020-417, in review, 2020.

Kaufman, Y. J., Koren, I., Remer, L. A., Tanré, D., Ginoux, P., and Fan, S.: Dust transport and deposition observed from the TerraModerate Resolution Imaging Spectroradiometer (MODIS) spacecraft over the Atlantic Ocean, J. Geophhys. Res., 110, D10S12, https://doi.org/10.1029/2003JD004436, 2005. 
Kiselev, A., Bachmann, F, Pedevilla, P., Cox, S. J., Michaelides, A., Gerthsen, D., and Leisner, T.: Active sites in heterogeneous ice nucleation-the example of K-rich feldspars, Science, 355, 367371, https://doi.org/10.1126/science.aai8034, 2017.

Klein, H., Haunold, W., Bundke, U., Nillius, B., Wetter, T., Schallenberg, S., and Bingemer, H.: A new method for sampling of atmospheric ice nuclei with subsequent analysis in a static diffusion chamber, Atmos. Res., 96, 218-224, https://doi.org/10.1016/j.atmosres.2009.08.002, 2010.

Kline, D. B.: Evidence of geographical differences in ice nuclei concentrations, Mon. Weather Rev., 91, 681-686, https://doi.org/10.1175/15200493(1963)091<0681:EOGDII>2.3.CO;2, 1963.

Kumai, M. and Francis, K. E.: Nuclei in Snow and Ice Crystals on the Greenland Ice Cap under Natural and Artificially Stimulated Conditions, J. Atmos. Sci., 19, 474-481, https://doi.org/10.1175/15200469(1962)019<0474:NISAIC>2.0.CO;2, 1962.

Lee, Y. H., Chen, K., and Adams, P. J.: Development of a global model of mineral dust aerosol microphysics, Atmos. Chem. Phys., 9, 2441-2458, https://doi.org/10.5194/acp-9-2441-2009, 2009.

Levin, E. J. T., McMeeking, G. R., DeMott, P. J., McCluskey, C. S., Carrico, C. M., Nakao, S., Stockwell, C. E., Yokelson, R. J., and Kreidenweis, S. M.: Ice-nucleating particle emissions from biomass combustion and the potential importance of soot aerosol, J. Geophys. Res.-Atmos., 121, 5888-5903, https://doi.org/10.1002/2016JD024879, 2016.

Lohmann, U.: Aerosol-Cloud Interactions and Their Radiative Forcing, Encyclopedia of Atmospheric Sciences, Elsevier Academic Press, Amsterdam, 17-22, https://doi.org/10.1016/B9780-12-382225-3.00052-9, 2015.

MadininAir, Ministry of Ecology, Energy, Sustainable Development and the Sea for monitoring air quality in Martinique: available at: https://www.madininair.fr/, last access: 23 June 2020.

Marcolli, C.: Deposition nucleation viewed as homogeneous or immersion freezing in pores and cavities, Atmos. Chem. Phys., 14, 2071-2104, https://doi.org/10.5194/acp-14-2071-2014, 2014.

Marinou, E., Tesche, M., Nenes, A., Ansmann, A., Schrod, J., Mamali, D., Tsekeri, A., Pikridas, M., Baars, H., Engelmann, R., Voudouri, K.-A., Solomos, S., Sciare, J., Groß, S., Ewald, F., and Amiridis, V.: Retrieval of ice-nucleating particle concentrations from lidar observations and comparison with UAV in situ measurements, Atmos. Chem. Phys., 19, 11315-11342, https://doi.org/10.5194/acp-19-11315-2019, 2019.

McCluskey, C. S., DeMott, P. J., Prenni, A. J., Levin, E. J. T., McMeeking, G. R., Sullivan, A. P., Hill, T. C. J., Nakao, S., Carrico, C. M., and Kreidenweis, S. M.: Characteristics of atmospheric ice nucleating particles associated with biomass burning in the US: Prescribed burns and wildfires, J. Geophys. Res.-Atmos., 119, 10458-10470, https://doi.org/10.1002/2014JD021980, 2014.

Möhler, O., Adams, M., Lacher, L., Vogel, F., Nadolny, J., Ullrich, R., Boffo, C., Pfeuffer, T., Hobl, A., Weiß, M., Vepuri, H. S. K., Hiranuma, N., and Murray, B. J.: The portable ice nucleation experiment PINE: a new online instrument for laboratory studies and automated long-term field observations of ice-nucleating particles, Atmos. Meas. Tech. Discuss., https://doi.org/10.5194/amt-2020-307, in review, 2020.
Moran-Zuloaga, D., Ditas, F., Walter, D., Saturno, J., Brito, J., Carbone, S., Chi, X., Hrab de Angelis, I., Baars, H., Godoi, R. H. M., Heese, B., Holanda, B. A., Lavrič, J. V., Martin, S. T., Ming, J., Pöhlker, M. L., Ruckteschler, N., Su, H., Wang, Y., Wang, Q., Wang, Z., Weber, B., Wolff, S., Artaxo, P., Pöschl, U., Andreae, M. O., and Pöhlker, C.: Long-term study on coarse mode aerosols in the Amazon rain forest with the frequent intrusion of Saharan dust plumes, Atmos. Chem. Phys., 18, 10055-10088, https://doi.org/10.5194/acp-18-10055-2018, 2018.

Morris, C. E., Conen, F., Huffman, J. A., Phillips, V., Pöschl, U., and Sands, D. C.: Bioprecipitation: a feedback cycle linking Earth history, ecosystem dynamics and land use through biological ice nucleators in the atmosphere, Glob. Change Biol., 20, 341-351, https://doi.org/10.1111/gcb.12447, 2014.

Müller, W.: Über den Einfluss meteorologischer Bedingungen auf die Gefrierkerndichte der Luft, Arch. Meteor. Geophy. A, 18, 5574, https://doi.org/10.1007/BF02247864, 1969.

Mülmenstädt, J., Sourdeval, O., Delanoë, J., and Quaas, J.: Frequency of occurrence of rain from liquid-, mixed-, and ice-phase clouds derived from A-Train satellite retrievals, Geophys. Res. Lett., 42, 6502-6509, https://doi.org/10.1002/2015GL064604, 2015.

Murray, B. J., Carslaw, K. S., and Field, P. R.: Opinion: Cloud-phase climate feedback and the importance of ice-nucleating particles, Atmos. Chem. Phys. Discuss., https://doi.org/10.5194/acp-2020852, in review, 2020.

Niemand, M., Möhler, O., Vogel, B., Vogel, H., Hoose, C., Connolly, P., Klein, H., Bingemer, H., DeMott, P., and Skrotzki, J.: A particle-surface-area-based parameterization of immersion freezing on desert dust particles, J. Atmos. Sci., 69, 3077-3092, https://doi.org/10.1175/JAS-D-11-0249.1, 2012.

ÖNORM M 5852: Standard ÖNORM M 5852:2007: Austrian standards, air analysis - sampling for continuous immission monitoring, Committee 139, 2007.

O’Sullivan, D., Murray, B. J., Ross, J. F., Whale, T. F., Price, H. C., Atkinson, J. D., Umo, N. S., and Webb, M. E.: The relevance of nanoscale biological fragments for ice nucleation in clouds, Sci. Rep.-UK, 5, 8082, https://doi.org/10.1038/srep08082, 2015.

O’Sullivan, D., Adams, M. P., Tarn, M. D., Harrison, A. D., VergaraTemprado, J., Porter, G., Holden, M. A., Sanchez-Marroquin, A., Carotenuto, F., Whale, T. F., McQuaid, J. B., Walshaw, R., Hedges, D., Burke, I. T., Cui, Z., and Murray, B. J.: Contributions of biogenic material to the atmospheric ice-nucleating particle population in North Western Europe, Sci. Rep.-UK, 8, 13821, https://doi.org/10.1038/s41598-018-31981-7, 2018.

Ott, W.: A Physical Explanation of the Lognormality of Pollutant Concentrations, J. Air Waste Ma., 40, 137-1383, https://doi.org/10.1080/10473289.1990.10466789, 1990.

Petters, M. D., Parsons, M. T., Prenni, A. J., DeMott, P. J., Kreidenweis, S. M., Carrico, C. M., Sullivan, A. P., McMeeking, G. R., Levin, E., Wold, C. E., Collett Jr., J. L., and Moosmüller, H.: Ice nuclei emissions from biomass burning, J. Geophys. Res., 114, D07209, https://doi.org/10.1029/2008JD011532, 2009.

PNRM: Parc Naturel Régional de la Martinique website, available at: http://pnr-martinique.com/la-charte-du-pnrm/, last access: 6 March 2020.

Pöhlker, M. L., Pöhlker, C., Ditas, F., Klimach, T., Hrabe de Angelis, I., Araújo, A., Brito, J., Carbone, S., Cheng, Y., Chi, X., Ditz, R., Gunthe, S. S., Kesselmeier, J., Könemann, T., Lavrič, J. V., 
Martin, S. T., Mikhailov, E., Moran-Zuloaga, D., Rose, D., Saturno, J., Su, H., Thalman, R., Walter, D., Wang, J., Wolff, S., Barbosa, H. M. J., Artaxo, P., Andreae, M. O., and Pöschl, U.: Longterm observations of cloud condensation nuclei in the Amazon rain forest - Part 1: Aerosol size distribution, hygroscopicity, and new model parametrizations for CCN prediction, Atmos. Chem. Phys., 16, 15709-15740, https://doi.org/10.5194/acp-16-157092016, 2016.

Pöhlker, M. L., Ditas, F., Saturno, J., Klimach, T., Hrab de Angelis, I., Araùjo, A. C., Brito, J., Carbone, S., Cheng, Y., Chi, X., Ditz, R., Gunthe, S. S., Holanda, B. A., Kandler, K., Kesselmeier, J., Könemann, T., Krüger, O. O., Lavrič, J. V., Martin, S. T., Mikhailov, E., Moran-Zuloaga, D., Rizzo, L. V., Rose, D., Su, H., Thalman, R., Walter, D., Wang, J., Wolff, S., Barbosa, H. M. J., Artaxo, P., Andreae, M. O., Pöschl, U., and Pöhlker, C.: Long-term observations of cloud condensation nuclei over the Amazon rain forest - Part 2: Variability and characteristics of biomass burning, long-range transport, and pristine rain forest aerosols, Atmos. Chem. Phys., 18, 10289-10331, https://doi.org/10.5194/acp-18-10289-2018, 2018.

Pöhlker, C., Walter, D., Paulsen, H., Könemann, T., RodríguezCaballero, E., Moran-Zuloaga, D., Brito, J., Carbone, S., Degrendele, C., Després, V. R., Ditas, F., Holanda, B. A., Kaiser, J. W., Lammel, G., Lavrič, J. V., Ming, J., Pickersgill, D., Pöhlker, M. L., Praß, M., Löbs, N., Saturno, J., Sörgel, M., Wang, Q., Weber, B., Wolff, S., Artaxo, P., Pöschl, U., and Andreae, M. O.: Land cover and its transformation in the backward trajectory footprint region of the Amazon Tall Tower Observatory, Atmos. Chem. Phys., 19, 8425-8470, https://doi.org/10.5194/acp19-8425-2019, 2019.

Prenni, A. J., Petters, M. D., Kreidenweis, S. M., Heald, C. L., Martin, S. T., Artaxo, P., Garland, R. M., Wollny, A. G., and Pöschl, U.: Relative roles of biogenic emissions and Saharan dust as ice nuclei in the Amazon basin, Nat. Geosci., 2, 402-405, https://doi.org/10.1038/ngeo517, 2009.

Prenni, A. J., DeMott, P. J., Sullivan, A. P., Sullivan, R. C., Kreidenweis, S. M., and Rogers, D. C.: Biomass burning as a potential source for atmospheric ice nuclei: Western wildfires and prescribed burns, Geophys. Res. Lett., 39, L11805, https://doi.org/10.1029/2012GL051915, 2012.

Prospero, J. M.: Saharan Dust Transport Over the North Atlantic Ocean and Mediterranean: An Overview, in: The Impact of Desert Dust Across the Mediterranean, edited by: Guerzoni, S. and Chester, R., Environmental Science and Technology Library, 11, Springer, Dordrecht, https://doi.org/10.1007/978-94017-3354-0_13, 1996.

Prospero, J. M. and Lamb, P. J.: African Droughts and Dust Transport to the Caribbean: Climate Change Implications, Science, 302, 1024-1027, https://doi.org/10.1126/science.1089915, 2003.

Rinaldi, M., Hiranuma, N., Santachiara, G., Mazzola, M., Mansour, K., Paglione, M., Rodriguez, C. A., Traversi, R., Becagli, S., Cappelletti, D. M., and Belosi, F.: Condensation and immersion freezing Ice Nucleating Particle measurements at Ny-Ålesund (Svalbard) during 2018: evidence of multiple source contribution, Atmos. Chem. Phys. Discuss., https://doi.org/10.5194/acp2020-605, in review, 2020.

Saturno, J., Holanda, B. A., Pöhlker, C., Ditas, F., Wang, Q., Moran-Zuloaga, D., Brito, J., Carbone, S., Cheng, Y., Chi, X., Ditas, J., Hoffmann, T., Hrabe de Angelis, I., Könemann, T.,
Lavrič, J. V., Ma, N., Ming, J., Paulsen, H., Pöhlker, M. L., Rizzo, L. V., Schlag, P., Su, H., Walter, D., Wolff, S., Zhang, Y., Artaxo, P., Pöschl, U., and Andreae, M. O.: Black and brown carbon over central Amazonia: long-term aerosol measurements at the ATTO site, Atmos. Chem. Phys., 18, 12817 12843, https://doi.org/10.5194/acp-18-12817-2018, 2018.

Schill, G. P., DeMott, P. J., Emerson, E. W., Rauker, A. M. C., Kodros, J. K., Suski, K. J., Hill, T. C. J., Levin, E. J. T., Pierce, J. R., Farmer, D. K., and Kreidenweis, S. M.: The contribution of black carbon to global ice nucleating particle concentrations relevant to mixed-phase clouds, P. Natl. Acad. Sci. USA, 2020, 202001674 https://doi.org/10.1073/pnas.2001674117, 2020.

Schmale, J., Henning, S., Decesari, S., Henzing, B., Keskinen, H., Sellegri, K., Ovadnevaite, J., Pöhlker, M. L., Brito, J., Bougiatioti, A., Kristensson, A., Kalivitis, N., Stavroulas, I., Carbone, S., Jefferson, A., Park, M., Schlag, P., Iwamoto, Y., Aalto, P., Äijälä, M., Bukowiecki, N., Ehn, M., Frank, G., Fröhlich, R., Frumau, A., Herrmann, E., Herrmann, H., Holzinger, R., Kos, G., Kulmala, M., Mihalopoulos, N., Nenes, A., O'Dowd, C., Petäjä, T., Picard, D., Pöhlker, C., Pöschl, U., Poulain, L., Prévôt, A. S. H., Swietlicki, E., Andreae, M. O., Artaxo, P., Wiedensohler, A., Ogren, J., Matsuki, A., Yum, S. S., Stratmann, F., Baltensperger, U., and Gysel, M.: Long-term cloud condensation nuclei number concentration, particle number size distribution and chemical composition measurements at regionally representative observatories, Atmos. Chem. Phys., 18, 2853-2881, https://doi.org/10.5194/acp-18-2853-2018, 2018.

Schneider, J., Höhler, K., Heikkilä, P., Keskinen, J., Bertozzi, B., Bogert, P., Schorr, T., Umo, N. S., Vogel, F., Brasseur, Z., Wu, Y., Hakala, S., Duplissy, J., Moisseev, D., Kulmala, M., Adams, M. P., Murray, B. J., Korhonen, K., Hao, L., Thomson, E. S., Castarède, D., Leisner, T., Petäjä, T., and Möhler, O.: The seasonal cycle of ice-nucleating particles linked to the abundance of biogenic aerosol in boreal forests, Atmos. Chem. Phys. Discuss., https://doi.org/10.5194/acp-2020-683, in review, 2020.

Schrod, J., Danielczok, A., Weber, D., Ebert, M., Thomson, E. S., and Bingemer, H. G.: Re-evaluating the Frankfurt isothermal static diffusion chamber for ice nucleation, Atmos. Meas. Tech., 9, 1313-1324, https://doi.org/10.5194/amt-9-1313-2016, 2016.

Schrod, J., Weber, D., Drücke, J., Keleshis, C., Pikridas, M., Ebert, M., Cvetkovi , B., Nickovic, S., Marinou, E., Baars, H., Ansmann, A., Vrekoussis, M., Mihalopoulos, N., Sciare, J., Curtius, J., and Bingemer, H. G.: Ice nucleating particles over the Eastern Mediterranean measured by unmanned aircraft systems, Atmos. Chem. Phys., 17, 4817-4835, https://doi.org/10.5194/acp17-4817-2017, 2017.

Schrod, J., Kleinhenz, D., Hörhold, M., Erhardt, T., Richter, S., Wilhelms, F., Fischer, H., Ebert, M., Twarloh, B., Della Lunga, D., Jensen, C. M., Curtius, J., and Bingemer, H. G.: Ice-nucleating particle concentrations of the past: insights from a 600-yearold Greenland ice core, Atmos. Chem. Phys., 20, 12459-12482, https://doi.org/10.5194/acp-20-12459-2020, 2020.

Schrod, J., Thomson, E. S., Weber, D., Kossmann, J., Pöhlker, C., Saturno, J., Ditas, F., Artaxo, P., Clouard, V., Saurel, J.M., Ebert, M., Curtius, J., and Bingemer, H. G.: Long-term ice nucleating particle concentrations by offline vacuum diffusion chamber measurements from the Amazon, the Caribbean, Central Europe, and the Norwegian Arctic, PANGAEA, available at: 
https://doi.org/10.1594/PANGAEA.925732, last access: 18 December 2020.

Serreze, M. C. and Francis, J. A.: The Arctic amplification debate, Climatic Change, 76, 241-264, https://doi.org/10.1007/s10584005-9017-y, 2006.

Smith, R. B., Minder, J. R., Nugent, A. D., Storelvmo, T., Kirshbaum, D. J., Warren, R., Lareau, N., Palany, P., James, A., and French, J.: Orographic Precipitation in the Tropics: The Dominica Experiment, B. Am. Meteorol. Soc., 93, 1567-1579, https://doi.org/10.1175/BAMS-D-11-00194.1, 2012.

Sobanski, N., Tang, M. J., Thieser, J., Schuster, G., Pöhler, D., Fischer, H., Song, W., Sauvage, C., Williams, J., Fachinger, J., Berkes, F., Hoor, P., Platt, U., Lelieveld, J., and Crowley, J. N.: Chemical and meteorological influences on the lifetime of $\mathrm{NO}_{3}$ at a semi-rural mountain site during PARADE, Atmos. Chem. Phys., 16, 4867-4883, https://doi.org/10.5194/acp16-4867-2016, 2016.

Soulage, G.: Methods of measurement of ice nucleus concentration, Pure Appl. Geophys., 60, 183-188, https://doi.org/10.1007/BF00874821, 1965.

Soulage, G.: Counting and electron microscope study of European ice nuclei, J. Rech. Atmos., 3, 219-229, 1966.

Stevens, B., Farrell, D., Hirsch, L., Jansen, F., Nuijens, L., Serikov, I., Brügmann, B., Forde, M., Linne, H., Lonitz, K., and Prospero, J. M.: The Barbados Cloud Observatory: Anchoring Investigations of Clouds and Circulation on the Edge of the ITCZ, B. Am. Meteorol. Soc., 97, 787-801, https://doi.org/10.1175/BAMS-D-14-00247.1, 2016.

Thomson, E. S., Weber, D., Bingemer, H. G., Tuomi, J., Ebert, M., and Pettersson, J. B. C.: Intensification of ice nucleation observed in ocean ship emissions, Sci. Rep.-UK, 8, 1111, https://doi.org/10.1038/s41598-018-19297-y, 2018.

Tobo, Y., Adachi, K., DeMott, P. J., Hill, T. C. J., Hamilton, D. S., Mahowald, N. M., Nagatsuka, N., Ohata, S., Uetake, J., Kondo, Y., and Koike, M.: Glacially sourced dust as a potentially significant source of ice nucleating particles, Nat. Geosci., 12, 253-258, https://doi.org/10.1038/s41561-019-0314$\mathrm{x}, 2019$.

Tunved, P., Ström, J., and Krejci, R.: Arctic aerosol life cycle: linking aerosol size distributions observed between 2000 and 2010 with air mass transport and precipitation at Zeppelin station, Ny-Ålesund, Svalbard, Atmos. Chem. Phys., 13, 3643-3660, https://doi.org/10.5194/acp-13-3643-2013, 2013.
Vali, G., DeMott, P. J., Möhler, O., and Whale, T. F.: Technical Note: A proposal for ice nucleation terminology, Atmos. Chem. Phys., 15, 10263-10270, https://doi.org/10.5194/acp-15-102632015, 2015.

Weinbruch, S., Wiesemann, D., Ebert, M., Schütze, K., Kallenborn, R., and Ström, J.: Chemical composition and sources of aerosol particles at Zeppelin Mountain (Ny Alesund, Svalbard): An electron microscopy study, Atmos. Environ., 49, 142-150, https://doi.org/10.1016/j.atmosenv.2011.12.008, 2012.

Welti, A., Müller, K., Fleming, Z. L., and Stratmann, F.: Concentration and variability of ice nuclei in the subtropical maritime boundary layer, Atmos. Chem. Phys., 18, 5307-5320, https://doi.org/10.5194/acp-18-5307-2018, 2018.

Welti, A., Bigg, E. K., DeMott, P. J., Gong, X., Hartmann, M., Harvey, M., Henning, S., Herenz, P., Hill, T. C. J., Hornblow, B., Leck, C., Löffler, M., McCluskey, C. S., Rauker, A. M., Schmale, J., Tatzelt, C., van Pinxteren, M., and Stratmann, F.: Ship-based measurements of ice nuclei concentrations over the Arctic, Atlantic, Pacific and Southern Ocean, Atmos. Chem. Phys. Discuss., https://doi.org/10.5194/acp-2020-466, in review, 2020.

Wex, H., Huang, L., Zhang, W., Hung, H., Traversi, R., Becagli, S., Sheesley, R. J., Moffett, C. E., Barrett, T. E., Bossi, R., Skov, H., Hünerbein, A., Lubitz, J., Löffler, M., Linke, O., Hartmann, M., Herenz, P., and Stratmann, F.: Annual variability of ice-nucleating particle concentrations at different Arctic locations, Atmos. Chem. Phys., 19, 5293-5311, https://doi.org/10.5194/acp-19-5293-2019, 2019.

Wilson, T. W., Ladino, L. A., Alpert, P. A., Breckels, M. N.,Brooks, Browse, J., Burrows, S. M., Carslaw, K. S., Huffman, J. A., Judd, C., Kilthau, W. P., Mason, R. H., McFiggans, G., Miller, L. A., Najera, J. J., Polishchuk, E., Rae, S., Schiller, C. L., Si, M., Temprado, J., Whale, T. F., Wong, J. P. S., Wurl, O., Yakobi-Hancock, J. D., Abbatt, J. P. D., Aller, J. Y., Bertram, A. K., Knopf, D. A., and Murray, B. J.: A marine biogenic source of atmospheric ice-nucleating particles, Nature, 525, 234-238, https://doi.org/10.1038/nature14986, 2015.

Zender, C. S., Bian, H., and Newman, D.: Mineral Dust Entrainment and Deposition (DEAD) model: Description and 1990s dust climatology, J. Gephys. Res., 108, 4416, https://doi.org/10.1029/2002JD002775, 2003. 